\title{
Andor Dudits a dozvuky preraffaelistických inšpirácií na jeho košickej mal'be*
}

\author{
Marta HERUCOVÁ
}

\begin{abstract}
Budapest painter Andor Dudits $(* 1866$ - 1944) created a monumental wall painting in honour of Francis II Rákóczi in the Cathedral of St Elizabeth in Košice from 1914 to 1916. It belonged to one of the last adaptations of the topic of anti-Habsburg resistance in painting in the Hungarian Kingdom. It was created based on a competition organized by the State Monuments Commission. With it, Dudits continued his previous Art Nouveau works in the sacral space (Bačka Topola, 1908; Brezno, 1909). Its concept and composition can be compared to the painting The Bridge of Life by Walter Crane, which was exhibited in the form of a graphic in Budapest. The impression of a mosaic, golden background, the look of Rákóczi's mother Jelena Zrinska, and a funeral procession point also to other Pre-Raphaelite inspirations.
\end{abstract}

Keywords: Royal Hungarian history painting, Art Nouveau, influences of Pre-Raphaelites, Francis II Rákóczi, iconography of stages of life, Walter Crane, Andor Dudits

Na severnej stene transeptu Dómu sv. Alžbety v Košiciach je monumentálna nástenná mal'ba na počest' heroizovaného sedmohradského kniežat'a a protihabsburského bojovníka Františka II. Rákociho. ${ }^{1}$ Vznikla počas I. svetovej vojny, v rokoch 1914

\footnotetext{
Štúdia vznikla s podporou projektu VEGA č. 2/0071/19 Symbolizmus na Slovensku.

Osobnost' Ferenca II. Rákóczịo de Felsốvadász (*1676 Borša, Zemplínska župa - †1735 Tekirdağ, Turecko) približuje GEBEI, S.: A Rákóçi-šabadságharc: 1703 - 1711. Budapest 2013 (s prehl'adom mad’arskej literatúry); TAJTÁK, L.: Povstanie Františka II. Rákociho v slovenských dejinách. In: Memorialis - historický spis slovenskéch stolic. Eds.: KOVAČKA, M. - AUGUSTÍNOVÁ, E. Martin 2008, s. 12-20; Povstanie Frantiskea Rákoczibo 1703-1711 (v novšom priblì̌ení). Rákoczi-szabadságharo 1703 - 1711 (üjabb megközelitésben). Ed.: KÓNYA, P. Prešov 2005.

2 Jeho predok Andrija Dudić z Orehovice (*1533 Budín †1589 Wrocław), ktorého zvečnil na nástennej malbe v Mad’arskom národnom archíve, bol známy humanista, pécssky biskup, diplomat a prívrženec reformácie, syn královského
}

až 1916, podl’a návrhu, ktorý sa rodil niekol'ko rokov v ateliéri budapeštianskeho maliara Andora Duditsa.

Dudits bol potomok chorvátsko-benátskej šlachtickej rodiny. ${ }^{2}$ Narodil sa v Pešti 24. júna 1866 ako druhé zo siedmich detí lekára Miklósa Duditsa a Idy

kancelára Hieronyma Dudića, ktorý pochádzal z Dalmácie, a Magdalény, rod. Sbardellati, ktorá pochádzala z benátskej patricijskej rodiny. Po smrti otca sa ho ujal strýc, vacovský biskup Agostino Sbardellati, ktorý mu umožnil vzdelanie. Známy sa stal aj tým, že na Tridentskom koncile presadzoval zmier s protestantmi a zrušenie celibátu. 1566 ho cisár Maximilián II. vyslal na královský dvor do Krakova. 1567 sa vzdal postu biskupa, prestúpil k protestantom a oženil sa s dvornou dámou Reginou Strass/Strasz. Pápež Pius V. uvalil na neho kliatbu. Po siedmich rokoch ovdovel, 1574 sa oženil s Elżbietou, rod. Zborowskou (*1538 - +1601), vdovou po grófovi Janovi Tarnowskom. Mal osem detí. Ked’že sa zasadzoval za zvolenie Maximiliána II. za pol’ského král'a a korunu získal Štefan Bátori/Báthory, Krakov opustil. 1578 si kúpil panstvo Paskov (pri Ostrave), ale život tam mu nevyhovoval a na d'alší rok panstvo predal. Usadil sa vo Wrocławe a v kruhu učencov sa venoval filozofii, astronómii a medicíne. Je pochovaný $\mathrm{v}$ tamojšom Kostole sv. Alžbety, kde má aj epitaf. ALMÁSI, G.: 
Amálie, rod. Képessy. ${ }^{3}$ Rodičia sa zoznámili a žili v Novom Bečeji vo Vojvodine, potom v Békescsabe, Pešti, opät' v Békescsabe, Debrecene/Debrecíne, Pribeníku na Zemplíne, kde bol otec domácim lekárom grófa Antona Mailátha de Székhely. Napokon sa usadili v Pešti. V Békescsabe sa spoznali s maliarom Michaelom Liebom, ktorý ich portrétoval; otec mu liečil problémy s očami. Lieb sa učil $\mathrm{v}$ ned'alekej obci Gyula, od roku 1863 v Pešti, kde si zmenil meno na Mihály Munkácsy. Portréty rodičov od Munkácsyho viseli v Duditsovom ateliéri do konca jeho života. Otec chcel, aby sa jeho syn stal umelcom, ale nedožil sa toho. Andor študoval na peštianskom piaristickom gymnáziu a potom maliarstvo vo Viedni a v Mníchove. Ked' ukončoval svoje štúdia v Budapešti, otec zomrel. Duditsovi rodičia boli rozvedení a matka sa v roku 1889 vydala za rodinného priatel’a Jánosa Regeleho, riaditel'a kancelárie Snemovne reprezentantov.

Andor Dudits sa oženil ako 34-ročný. Dňa 12. februára 1901 si v Budapešti zobral za manželku svoju modelku Stefániu Pécsi. ${ }^{4}$ Pochádzala zo židovskej rodiny, bola dcérou kvetinára Emanuela Pécsiho (Fuchsa) a Júlie, rod. Rieger. Mali syna Andora ml., ${ }^{5}$ ktorý sa stal lekárom, pôsobil v Budapešti, Szegede a Leviciach; mal syna a dvoch vnukov. Duditsova

The Uses of Humanism. Andreas Dudith (1533-1589), Johannes Sambucus (1531-1584), and the East Central European Republic of Letters. Leiden 2009; PURATIĆ, Ž.: Hrvatski humanist Andrija Dudić. In: Mogućnosti, 38, 1991, č. 8-10, s. 725-736.

3 Otec *1835 Mátraszőlős, Novohradská župa - †1892 Budapešt'; matka *1844 Budín - †1895 Budapešt'; Andora krstili v r. k. kostole v Józsefvárosi 28. 6. 1866 ako Andreas Josephus Stephanus. Súrodenci: Miklós István (*†1865 Békescsaba), Ilona Anna Vilhelmina (*†1867 Békescsaba), obaja zomreli krátko po narodení, nasledovali Miklós József Tibor (*1869 Debrecen - † pred 1892), János (*1871 Vel'ké Trakany, Zemplínska župa - † pred 1892), Pál Oszkár (*1872 Pribeník, Zemplínska župa), ktorý bol úradník, redaktor a potom majitel' vydavatel'stva, 1913 sa oženil so Zsófiou Krcsmarik a 1919 sa rozviedol. Najmladšia bola Irma Erzsébet Katalin Júlia (*1877 Budapešt'), ktorá sa vydala za Sándora Palaszovského, mala štyri deti (Andora, Bélu, Edit a Mariannu). REISZ, C. T.: Dudits Andor festőművész családi kapcsolatai. In: Turul, 86, 2013, č. 3, s. 108-116 (tu s. 113).

\footnotetext{
4 *1881 Budapešt' - †1954.

5 *1904 Budapešt' - †1943 Levice, Tekovská župa.
}

švagriná, najstaršia sestra jeho manželky, Olga Pécsi, vyd. Garami, ${ }^{6}$ sa druhýkrát vydala za sochára Ede Margóa (Morgensterna), s ktorým Dudits spolupracoval pri tvorbe prvého (nerealizovaného) návrhu na košickú mal'bu.

Dudits s rodinou býval od roku 1903 na Kelenhegyi út 12 v XII. okrese v Budapešti (na dome nechala rodina v roku 2015 umiestnit' pamätnú tabul'u). Venoval sa rôznym, najmä historickým, námetom. Viaceré štátne objednávky získal od kontroverzného ministra kultúry Kuna Klebelsberga. ${ }^{7}$ Ten ho v roku 1922 menoval za profesora maliarskych techník na Vysokej škole výtvarných umení. Od roku 1923 predsedal Benczúrovej spoločnosti. Po smrti ministra ho prepustili a stratil aj možnost' realizácie d'alších projektov. Prepojenie s Klebelsbergom spôsobilo, že upadol do nemilosti. Zomrel 7. septembra 1944 vo veku 78 rokov. Jeho náhrobok na Farkasrétskom cintoríne bol zničený. ${ }^{8}$

Euforický záujem o pripomínanie si vel'kých postáv uhorských dejín, ku ktorým patril aj Rákoci, eskaloval u predošlých generácií mad’arských národovcov, ktoré zažili prehru v revolúcii 1848/1849 a následné represálie zo strany habsburského cisárskeho dvora. ${ }^{9}$ Pokračoval v časoch mad’arských mocenských zápasov, korunovaných úspechom

\footnotetext{
6 *1877 Pešt' - †1973 Budapešt'.

*1875 Pecica, Aradská župa - †1932 Budapešt'.
}

8 Andor Dudits nemal doteraz individuálnu výstavu a nemá ani monografiu. Výskumu jeho osobnosti sa najviac venuje historik a archivár Csaba T. Reisz. REISZ, C. T.: Dudits Andor festőművész délvidéki művei. In: Apхеoн (Archeon), časopis Archívu Vojvodiny, 1, 2018, č. 1, s. 363-375; REISZ 2013, c. d. (v pozn. 3); tiež MENDÖL, Z.: Dudits Andor. In: Pécs Lexikon I. Pécs 2010, s. 181; Archivum Regni, Regnum Archivi : the Hungarian National Archives. Ed.: ÉRSZEGI, G. Budapest 2006; RÉVÉSZ, E.: Dudits, Andor. In: SAUR Allgemeines Künstlerlexikon 30. München - Leipzig 2001, s. 248-249.

9 Napr. peštiansky Hauptz̨ensor Josef Prottmann zakázal vystavit' Madarászov obraz Kuruc a labanc (1853), po incidente musel autor zmenit' jeho názov na Dvaja bratia. 1863 bol zas vydaný zákaz divadelnej hry o živote Františka II. Rákociho. RÉVÉSZ, E.: Kuruc és labanc - Két testvér - Életrajz Erdély múltjából. Madarász Viktor első történeti festménye 1855ből. In: Müvészettörténeti Értesitô, 47, 1998, č. 1-2, s. 141-151; SOKOLOVSKÁ, E.: Mesto Banská Bystrica 1850 - 1922. Inventár. Banská Bystrica 1982, inv. č. E1-192. 


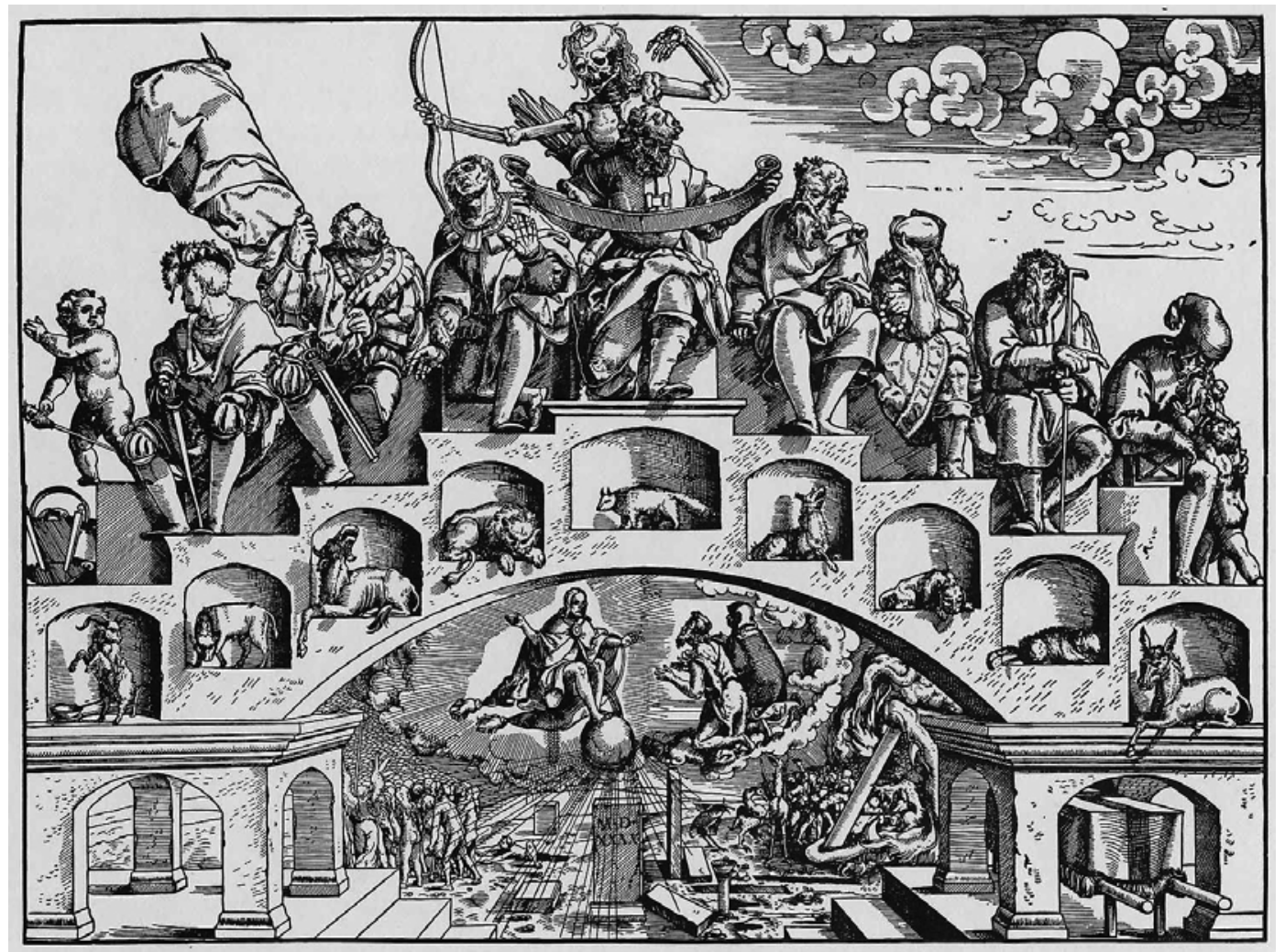

Obr. 1: Cornelis Anthonis₹: (sc.) - Jörg Breu Jr. (del.): Die Lebensalter des Mannes, okolo 1540, drevorez na papieri, Herzogliches Museum Gotha. Zdroj: https:// commons.wikimedia.org/wiki/File:Jörg_Breu_dJ_Die_Lebensalter_des_Mannes.jpg

rakúsko-mad'arského vyrovnania (1867) a zavŕšil sa v období príprav osláv tisícročia príchodu uhorských kmeňov do Panónie (1896). ${ }^{10}$ Vtedy sa Andor Dudits obrátil k historickej mal'be a pri príležitosti milénia vytvoril monumentálny obraz František II. Rákoci prichádza na Ónodský snem. Bol určený pre župný dom v Sátoraljaújhelyi, vzdialený len pár kilometrov od Rákociho rodiska. ${ }^{11}$ Pripomínal povestné zhromaždenie, ktoré sa odohralo 30. mája 1707. Povstalci na ňom zbavili Habsburgovcov vlády nad Uhorskom a zabili alebo zajali tých, ktorí nesúhlasili s pokračovaním pät' rokov trvajúcich bojov za nezávislost'. ${ }^{12}$

\footnotetext{
${ }^{10}$ Oslavám predchádzal problém určenia roku príchodu. Preto sa v októbri 1882 minister náboženstva a školstva Augustín/ Ágoston Trefort (*1817 Humenné, Zemplínska župa - †1888 Budapešt') obrátil na Uhorskú akadémiu vied, ktorá tým poverila štyroch historikov: Tivadara Botku, Gyulu Paulera, Ferencza Salamona a Károlya Szabóa. Ich odpovede sa rôznili, čas príchodu určili v rozmedzí rokov 884 až 897 . Napokon Uhorský snem schválil zákonom rok osláv 1895, avšak v roku 1893 minister hospodárstva požiadal o ich preloženie na rok 1896. KOMORA, P.: Milenárne oslavy v Uhorsku roku 1896 a ich vnímanie v slovenskom prostredí. In: Slovensko na začiatku 20. storočia. Eds.: PODRIMAVSKÝ, M. - KOVÁČ, D. Bratislava 1999, s. 100-116.
}

${ }^{11}$ Obraz s mad’arským názvom II. Rákóczi Ferenc bevonulása az ónodi országgyuulésre (1896) bol počas II. svetovej vojny odnesený do Sovietskeho zväzu; dnes je vo Vojensko-historickom ústave a múzeu/Hadtörténeti Intézet és Múzeum v Budapešti. RÉVÉSZ 2001, c. d. (v pozn. 8), s. 248. (Olejo) tlač obrazu sa nachádza v Múzeu mesta Bratislavy aj v SNM-Spišskom múzeu v Levoči.

${ }^{12}$ Mečmi rozsekali vyslanca Turčianskej stolice Melchiora Rakovského, popravili Krištofa Okolicsányiho a viacerých uväznili. Bližšie KÓNYA, Peter: Ónodsky snem v kontexte udalostí povstania Františka II. Rákocziho. In: KOVAČKA - AUGUSTÍNOVÁ (eds.) 2008, c. d. (v pozn. 1), s. 27-40. 
Zásluhy na spracovaní osudov Františka II. Rákociho ${ }^{13}$ mal Kálmán Thaly, ${ }^{14}$ ktorý sa histórii venoval zo záluby. Stredoškolské vzdelanie získal v Bratislave a Pápe. Potom začal študovat' právo v Pešti, ale pre buričstvo musel ujst' do Sedmohradska. Tam sa z neho stal nadšenec pre kurucov. Po návrate pôsobil ako redaktor a potom ako stredoškolský profesor dejín mad’arskej literatúry na peštianskom hlavnom ev. ref. gymnáziu. Koniec života strávil v Bratislave..$^{15}$ Zanietené skúmanie uhorskej histórie a práce, ktoré publikoval, ${ }^{16}$ mu priniesli prijatie za člena Uhorskej akadémie vied a otvorili dvere do vyšších politických a cirkevných kruhov. Stal sa poslancom Uhorského snemu za mesto Debrecen a jedným z hlavných organizátorov miléniových osláv. ${ }^{17}$ Za podpory vlády, vedenej Istvánom Tiszom, vyhladal v roku
1889 Rákociho hrob v Trácii na vtedajšom území Osmanskej ríše. $\mathrm{Na}$ ceste ho sprevádzal titulárny biskup a cirkevný historik Vilmos Fraknói (Frankl) ${ }^{18}$ a orientalista Armin Vámbéry (Bamberger). ${ }^{19}$ Thaly následne inicioval prevezenie pozostatkov Rákociho a jeho blízkych do Uhorska. ${ }^{20}$ Záležitost' komplikovali dohady o mieste znovu pochovania a takmer 200-ročný výnos označujúci protihabsburských povstalcov za vlastizradcov, ktorý cisár František Jozef I. zrušil až v roku 1904. V decembri toho istého roku boli odkryté hroby Rákociho a jeho blízkych a ich ostatky dočasne umiestnené v Konštantínopole (Istanbule). Vyše roka trvalo zabezpečit' všetko potrebné. Po opatreniach uhorského ministerského predsedu Sándora Wekerleho sa na jeseň 1906 uskutočnil slávnostný prevoz do Košíc, ${ }^{21}$ kde

és queer irányulások a magyar költészetben. Pozsony 2014, 3. čast' (recenziu knihy publikoval József Keserü in World Literature Studies, 8, 2016, č. 2, s. 107-109); SOÓS, I.: Thaly Kálmán. In: BEKE, L. - GAZDA, I. et al.: Nemzeti évfordulóink 2009. Budapest 2008, s. 58-59.

${ }^{16}$ Napr. THALY, K.: Arcbivum Rákóczianum I - III. Budapest 1873 - 1889; THALY, K.: Rákóczi és a sajtószabadság. In: Magyar Könyuszemle, 5, 1880, s. 394; THALY, K.: II. Rákóczi Ferencz: Pozsony 1881; THALY, K.: Rákóczi-emlékeek Törökországban és II. Rákóczi Ferencz fejedelem hamvainak föltalálása. Budapest 1893.

${ }^{17}$ KOROMPAI, B.: Koloman Thaly. In: Rákóczi 110 rokov v Košiciach. Ed.: PALENČÁROVÁ, I. Košice 2016, s. 113-116.

18 *1843 Mojmírovce, Nitrianska župa - †1924 Budapešt’.

19 *1832 Sv. Jur, Bratislavská župa - †1913 Budapešt'.

${ }^{20}$ Bližšie napr. turkológ SERES, I.: A törökországi bujdosók sírhelyei és a magyar tudóstársadalom. In: Magyar Tudomány - A Magyar Tudományos Akadémia folyóirata, 12, 2006, č. 166, s. $1464-1475$.

${ }^{21}$ Pozostatky previezli parníkom Kelet (Východ) z Konštantínopolu do Constanțe, kam dorazili 27. 10. Prevoz pokračoval špeciálnym vlakom Uhorských štátnych železníc do Orșovy a do Budapešti. Tam smútočné koče išli z Keleti-pályaudvar (Východnej stanice) do Baziliky sv. Štefana; koč s Tökölim/ Thökölym do ev. kostola na Deák tér. Koč s Rákocim sprevádzali zástupcovia žúp, v ktorých sa nachádzali Rákociho majetky, a predstavitelia mesta Kluž/Cluj-Napoca; koč s Tökölim sprevádzali zástupcovia Spišskej župy a mesta Kežmarok. Vlak s ostatkami mal odchod z Budapešti 28. 10. o 19:50 a príchod do Košíc 29. 10. o 5:16. Na základe 
mal Rákoci počas povstania svoje stanovište, a kde boli pochovaní jeho starí rodičia. ${ }^{22}$ Pre miesto znovu pochovania bola upravená severná podzemná krypta Dómu sv. Alžbety. ${ }^{23}$ Úpravy naprojektoval architekt a pamiatkar Fridrich/Frigyes Schulek ${ }^{24}$ a realizoval stavitel Alexander/Sándor Aigner. ${ }^{25}$ Bola to osvedčená a uznávaná dvojica, ich spoločným dielom bol napr. Matyástemplom v Budíne. Priestor pri vchode do hrobky, ${ }^{26}$ ktorej architektúra bola prispôsobená gotickému chrámu, bol dotvorený Duditsovou nástennou mal'bou. Bola vybraná na základe 3. sút’aže,

nariadení bol prevoz výhradne v nočných hodinách. Na biskupov príkaz pri trati stáli muži s fakl’ami a zvonili zvony. Pietny akt znovu uloženia ostatkov Františka II. Rákociho, Heleny, rod. Zrínskej, Jozefa Rákociho, Mikuláša Bercsényiho, Kristíny, rod. Csáky, Antona Eszterházyho a Michala Sibrika sa v košickom dóme konal 29. 10. za pontifikátu košického biskupa Žigmunda Bubicsa; znovu uloženie ostatkov Imricha Tököliho sa v kežmarskom ev. chráme uskutočnilo 30. 10. Košická slávnost' začala o 8:00 v smútočnom stane omšou, ktorú slúžil košický pomocný biskup Augustín FischerColbrie za účasti r. k. biskupov, satumarského, rožňavského a spišského a g. k. biskupov, prešovského a mukačevského. Potom zaspieval Košický spevokol, Kálmán Thaly predniesol reč, po ktorej zaznela hymna Szózat, rozozvučali sa zvony a počas 24 sálv sa sprievod vydal do dómu. Po skončení liturgie delegácie kládli k rakvám vence. 16:30 sa brány dómu zatvorili. Opät' sa rozozvučali zvony a počas 24 sálv umiestnili rakvy do krypty. Večer zneli z veží kurucké melódie. 20:00 sa v divadle konalo slávnostné predstavenie. KOROMPAI 2016, c. d. (v pozn. 17), s. 115-116; KERÉKGYÁRTÓ, J.: Pohrebné zvony Františka II. Rákócziho. In: PALENČÁROVÁ 2016, c. d. (v pozn. 17), s. 117-131 (tu s. 123-124); ZUBKO, P.: Pohreb Františka II. Rákócziho a košické biskupstvo v roku 1906. In: PALENČÁROVÁ 2016, c. d. (v pozn. 17), s. 132-139; Rákoczy hamvak. In: Felvidéki Szemle, 19, 1894, č. 10 (8. 2.), s. 3.

${ }^{22}$ Rákoci býval v Košiciach v budove hornouhorského kapitanátu na Hlavnej ul. č. 88 (dnes budova Slovenského technického múzea). Na bohoslužby chodil oproti do františkánskeho kostola alebo do jezuitského (dnes premonštrátskeho) kostola, ktorého fundátormi boli jeho starí rodičia: sedmohradský vojvoda Juraj II. Rákoci (*1621 Sárospatak, Zemplínska župa - †1660 Oradea, Biharská župa) a Žofia, rod. Bátori/Báthory (*1629 Şimleu Silvaniei, Sedmohradsko - †1681 Mukačevo, Berežská župa). DUCHOŇ, J.: František II. Rákoczi a jeho Košice. Košice 2005.

${ }^{23}$ Zriadenie hrobky bolo ukotvené v zákone. Najprv sa uvažovalo o Kaplnke sv. Štefana, potom o rôznych častiach transeptu a napokon o krypte pod Kaplnkou sv. Štefana. Okrem tejto krypty bolo v dóme d'alších šest' krýpt: pod stredom, pod oltárom Najsv. Trojice, pod Kaplnkou sv. Jána ktorú vypísala Štátna pamiatková komisia/Múemlékeek országos bizottsága (MOB) rozhodnutím ministra náboženstva a školstva Alberta Apponyiho. Komisii predsedal predseda $M O B$, právnik, ministerský radca a umelecký kritik barón Gyula Forster de Pusztakér. ${ }^{27}$ Tvorili ju osemnásti členovia: Kálmán Thaly, zástupcovia Štátnej rady výtvarných umení/Orsqágos Képzómúvészeti Tanács, MOB, Uhorského spolku umelcov/ Magyar Képrómüvészeke Egyesülete, Uhorského zväzu inžinierov a architektov/Magyar Mérnök-és Épitészegylet a Spolku architektov/Ëpitömüvészek Sqövetsége.

Nepomuckého, pod Kaplnkou sv. Kríža, pod Kaplnkou Metercie a pod niekdajším oltárom Smrti Panny Márie. Pri rekonštrukcii dómu v rokoch 1877 až 1896 boli ponechané tri krypty: severná pod Kaplnkou sv. Štefana (pre Rákociho a jeho blízkych), južná pod Kaplnkou Metercie (pre košických biskupov) a pred niekdajším oltárom Smrti Panny Márie (pre Csákyovcov).

24 *1841 Pešt' - †1919 Balatonlelle, Šomodská župa.

25 *1854 Timișoara, Temešská župa - †1912 Budapešt'.

${ }^{26}$ Do hrobky sa vstupuje po sedemnástich schodoch. Pri mreži je postava s kapucňou držiaca rákociovský erb. Štyri sarkofágy vytvorili Anselmo Andreetti a František Mikula. V strede je sarkofág Rákociho, jeho matky Heleny a ich syna Jozefa, napravo sarkofág kuruckého generála grófa Antona Eszterházyho z Galanty a Forchtenau, nalavo dvorného majstra Mikuláša Sibrika z Óváru a Szarvaskendu. Vo štvrtom sarkofágu sú pochovaní Mikuláš Bercsényi zo Székesu a jeho druhá manželka Kristína, rod. Csáky z Körösszeghu a Adorjanu. Všetci zomreli v Tekirdağe (lat. Raedestum, mad'. Rodostó, slov. Rodošto). Rákociho sarkofág je zo šiklóšskeho mramoru, Eszterházyho, Sibrikov a Bercsényiho z kapriorského mramoru. Zdobia ich erby a nápisy. Pozostatky Rákociho sú v drevenej truhle z cyprusu, vloženej do medenej truhly zaliatej v spojoch olovom. Podhlavník je naplnený zemou z Borše a Vel'kého Šariša. Rákociho srdce zaslal na jeho žiadost' Mikes Kelemen do kláštora v Grosbois. Pozostatky Heleny, rod. Zrínskej, sú tiež v drevenej truhle z cyprusu, vloženej do medenej truhly. Podhlavník má naplnený zemou z Mukačeva. Nad kryptou, v Kaplnke sv. Štefana, sú umiestnené ich pôvodné náhrobné tabule: Rákociho a Heleny, rod. Zrínskej, sú z r. k. Kostola sv. Beňadika - Saint Benoît Katolik Kilisesi v Istanbule (zv. francúzsky, pretože ho obnovili marseillskí obchodníci a premenili na miesto pochovávania francúzskych diplomatov); Bercsényiho a Sibrikova tabula sú z g. k. Kostola Panny Márie - Panagia Rheumatocratissa Ortodoks Kilisesi v Tekirdağe. WICK, B.: Kassa régi siremlékei : XIX. - XVIII. század. Kassa 1933, s. 135-136.

27 *1846 Ostrihom, Ostrihomská župa - †1932 Budapešt’. 
Išlo o trikrát opakovanú sút'až v rokoch 1906, 1908 a 1912. Sút'aže sa mohol zúčastnit' každý občan Uhorska. Dudits sa zúčastnil druhej a tretej. V 1. sút’aži sa návrhy posielali do Uhorského národného múzea a museli obsahovat' model $\mathrm{v}$ pomere 1:5, nákres, opis a rozpočet. Odmena za vít’azný návrh bola 6000 korún. Prišlo jedenást' návrhov, ale žiaden nevyhovoval. Do 2. sút'aže prišlo 23 návrhov, z ktorých komisia určila vít’azný návrh od sochára Barnabása Hollóa a architekta Gézu Györgya; Dudits so svojim vyššie spomínaným príbuzným sochárom Ede Margóm a architektom Kálmánom $\operatorname{Luxom}^{28}$ sa umiestnili na štvrtom mieste. Ich návrh bol v secesnom štýle a verejnosti ho predstavili v časopise Müvészet. ${ }^{29}$ Nový minister náboženstva a školstva gróf Ján Zichy de Zich et Vásonkeő vyzval vít’azov, aby priamo v dóme vytvorili model s ukážkami materiálov. Po jeho preskúmaní v zime 1910 bol vyhodnotený ako nevhodný. Na zasadnutí $M O B$, ktorého sa zúčastnili architekti József Kauser, Virgil Nagy a Fridrich Schulek, sochár Alojz Stróbl, maliari Július Benczúr a Andor Dudits, sa dohodlo, že bude 3. sút'až len pre maliarov. Spomedzi ôsmich zúčastnených Dudits vyhral. ${ }^{30}$

Duditsov návrh nenadväzoval na dovtedajšie maliarske spracovania rákociovskej témy; tie sa niesli na vlne (francúzskeho) romantizmu a (mníchovského)

\footnotetext{
28 *1880 Brezno-Bujakovo, Zvolenská župa - †1961 Budapešt'.

${ }^{29}$ Müvészet, 9, 1910), s. 163. Pozri aj A Rákoczi-síremlék pályazat. In: Eperjesi Lapok, 37, 1909, 12. 9., s. 4. (o sochárskom súbehu); Das Denkmal Franz Rákoczys II. im Kaschauer Dom. In: Gren₹bote, 34, 1905, 19. 3.

${ }^{30}$ REISZ, C. T.: A kassai Rákóczi-freskó emléktáblái. In: Magyar nemzeti léveltár. Dostupné online: https://mnl.gov.hu/ $/ \mathrm{mnl} / \mathrm{ol} /$ hirek/a_kassai_rakoczi_fresko_emlektablai, publ. 2. 7.2018.

31 *1830 Štítnik, Gemerská župa - †1917 Budapešt'. Bližšie o maliarovi KRASZNAI, R.: Egy magyar festô a francia fóvárosban: Madarász Viktor párizsi pályafutása. In: „A temetó lángész:" - Egy kultuszkép története. Eds.: BORUS, J. - KARDOS, E. Budapest 2017, s. 12-82.
}

${ }^{32}$ Vo Wiener Neustadte ho uväznili za to, že s Bercsényim chcel nadviazat' styky s protihabsbursky naladeným francúzskym králom Ludovítom XIV. MOJDIS, J.: Povstanie Františka Rákociho II. a jeho vnímanie vo Francúzsku. In: Obdobie protireformácie v dejinách slovenskej kultúry ₹. hladiska stredoeurópskeeho kontextu. Ed.: DORUL'A, J. Bratislava 1998, s. 106-111. naturalizmu. Témy sa medzi prvými chopil Viktor Madarász, účastník revolúcie 1848/1849, počas pobytu v Paríži, kde žal úspechy za obrazy uhorských rebelov. ${ }^{31}$ Vo francúzskej národnej knižnici našiel Rákociho rukopisy. Zaujal ho opis ako Rákoci uväznený vo Wiener Neustadte ${ }^{32}$ sedával pri zamrežovanom okne a kŕmil labute plávajúce po vode obmývajúcej múry žalára. ${ }^{33} \mathrm{~V}$ roku 1858 Madarász namal'oval Zatknutie Petra Zrínskeho (Rákociho starého otca, popraveného za sprisahanie proti cisárovi) a v roku 1859 Helenu Zrínsku pred súdom (Rákociho matku, internovanú vo Viedni potom ako cisárske vojská dobyli mukačevský hrad Palanok). Všetky tieto diela poukazovali na pocit'ované krivdy spáchané zo strany Habsburgovcov. Madarász stvárnil aj Ónodský snem (1879). Obraz korešpondoval so staršími, obdobne dramatickými, kompozíciami Móra Thana a Somu Orlai Petricha/Petrića. ${ }^{34}$ Dominuje na ňom mohutná postava vysokého tmavovlasého kučeravého Františka II. Rákociho, povstalcami zvoleného za panujúce knieža dobytých území. Pri nohách mu leží jeho mŕtvy odporca a naokolo stoja odhodlaní a bojovo naladení muži.

Generačne mladší bard uhorskej historickej mal'by Július Benczúr namal'oval Zatknutie Františka II. Rákociho vo vel'košarišskom kaštieli, ku ktorému došlo 18. apríla $1700 .{ }^{35}$ Rákociho zobrazil v komnate

\footnotetext{
${ }^{33} \mathrm{~V}$ roku 1905 ho to inšpirovalo k namal'ovaniu obrazu, ktorý je dnes v Rákospalotai Múzeu v Budapešti (dar maliarovej dcéry). MATITS, F.: Madarász Viketor halálának 80. évfordulójának emlékére szervezett kiállitás. Nyíregyháza 1997, s. 8-9; KACZIÁNY, Ö.: Madarász Viktor. In: Müvészet, 3, 1904, č. 4, s. 249-257.
}

${ }^{34}$ Mór Than (*1828 Bečej, Báčsko-Bodrocká župa, Vojvodina - †1899 Terst): František. II. Rákoci na Ónodskom sneme, 1864, olej, plátno, 131 x $174 \mathrm{~cm}$, Mad'arský parlament, Budapešt'. Than sa zúčastnil revolúcie 1848/1849. Maliarstvo študoval na viedenskej akadémii, potom odišiel do Paríža (1855), Nemecka, Belgicka a Ríma. Soma Orlai Petrich (*1822 Mezőberény, Békešska župa - †1880 Budapešt'): Ónodský snem, 1865-1866, olej, plátno, 150 x $220 \mathrm{~cm}$, súkromný majetok. Orlai Petrich študoval v Pešti, vo Viedni a v Mníchove (od 1850). Datovanie obrazu podl'a GALAMB, Z.: Orlai Petrics Soma. Mezőberény 2011, s. 187, kat. č. 316. Viktor Madarász: Ónodský snem, 1879, olej, plátno, 186 x 263 cm, Déri Múzeum, Debrecen.

35 Július Benczúr (*1844 Nyíregyháza, Sabolčská župa - †1920 Szécsény, Novohradská župa): Zatknutie Františka II. Rákociho, 1869, skica, olej, plátno, 44,5 x 58,8 cm, MNG Budapešt' (inv. č. 78.130T). Originál obrazu sa nachádza v Rumunskom 


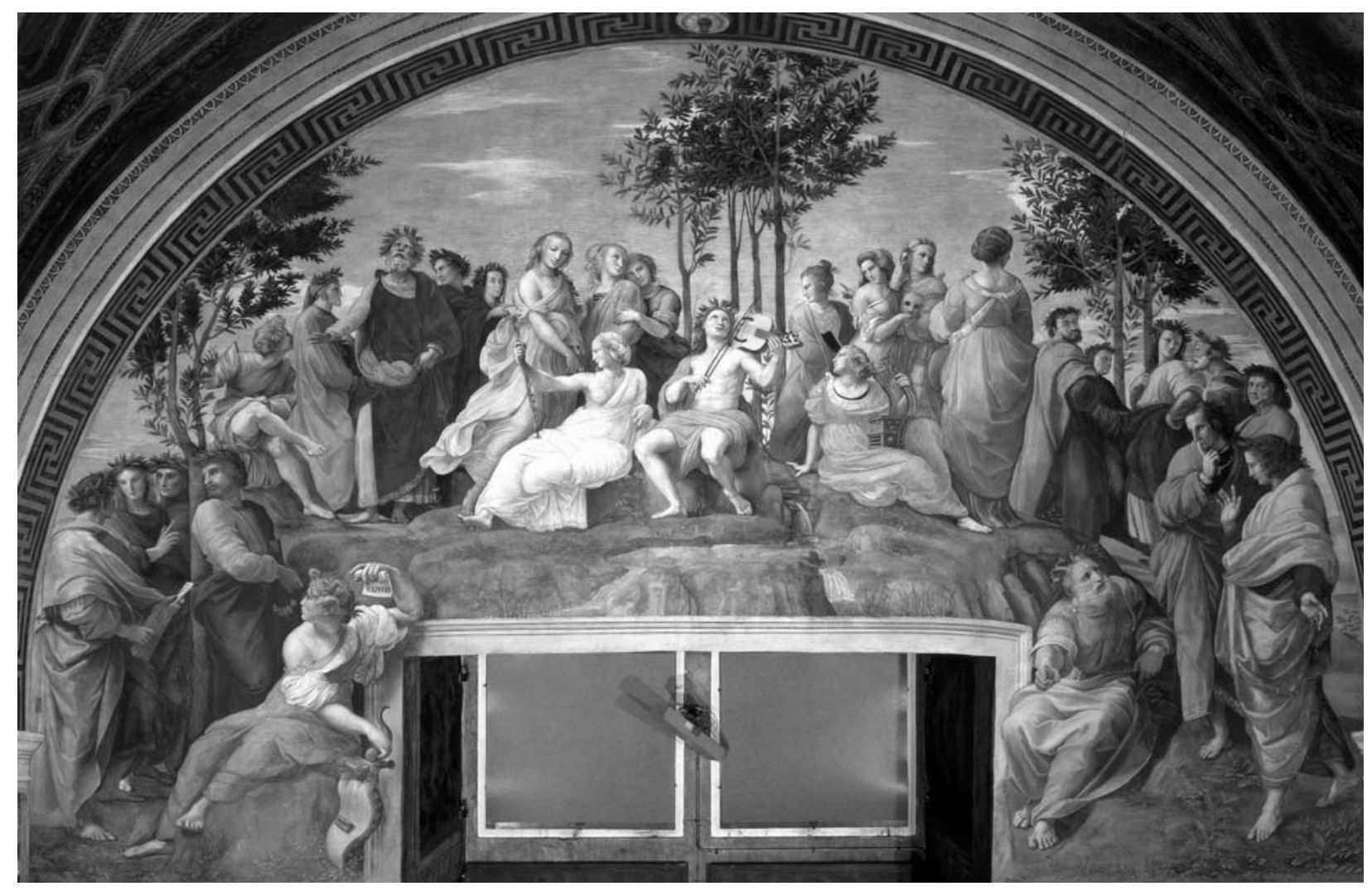

Obr. 2: Raffael: Parnas, 1509 - 1511, freska, Apoštolský palác, Vatikán. Zdroj: https:// commons.wikimedia.org/wiki/File:Rafael_-_El_Parnaso_(Estancia_del_Sello,_Roma,_1511).jpg

ako stojí pri lôžku manželky Charlotte Amalie a berie ju do náruče. Očakávala narodenie ich tretieho syna Jozefa, preto má pri sebe zobrazenú pestúnku a kolísku. Všetci zdesene upierajú zrak do zadnej časti komnaty, kde sa z prítmia vynárajú prichádzajúci vojaci. Dramatickost' výjavu je dosiahnutá prudkým osvetlením hlavných postáv a ponurost'ou priestoru s nepriatel'skými narušitel'mi. Mal'ba s uvol'neným maliarskym rukopisom má sviežu farebnú skladbu a pôsobivú hru svetla a tieňa.

Popri scénických výjavov sa $\mathrm{v}$ uhorskom maliarstve objavovali aj historické portréty Rákociho.

národnom múzeu umenia v Bukurešti. Kaštiel', v ktorom ho zatkli, bol po požiari 1947 zbúraný. SÁROSSY, Š.: Kaštiel' vo Vellkom Šariši. Prešov 2010.

\footnotetext{
${ }^{36}$ Neznámy autor (podl’a Ádáma Mányokiho): František II
}

Na prelome 19. a 20. storočia patrili k oblúbenej výbave reprezentačných priestorov obecnej, krajinskej alebo štátnej správy, viseli v župných domoch, radniciach, kasínach a podobne. Neznámi autori zväčša kopírovali staršie diel ${ }^{36}$ alebo sa nechali nimi inšpirovat'. Rákociho historický portrét namal'oval aj vynikajúci maliar Fülöp Elek de László (Filip Alex de Laub) v miléniovom roku, ako aj viacerí Benczúrovi žiaci: Július Štetka/Gyula Stetka, Imre Révész (Csebrai) a Július Éder. ${ }^{37}$ Modernejšie postupy maliarstva, stojace na estetických účinkoch pastóznosti farieb, deleného rukopisu, štylistických

Rákoci, koniec 19. storočia, olej, plátno, 79 × 63 cm, SNM-Spišské múzeum v Levoči (inv. č. SM-2587).

${ }^{37}$ Fülöp Elek de László (*1869 Budapešt’ - †1937 Londýn): František II. Rákoci, 1896, olej, plátno, 177 x 100 cm, Rákociho 
skratiek, či náznakovosti jednotlivých motívov, vykazujú obrazy s rákociovskými témami od sedmohradského maliara Lászlóa Patakyho ${ }^{38}$ alebo od slovensko-mad'arského maliara Imricha Gregussa/ Greguša. ${ }^{39}$ Obaja zbierali svoje umelecké skúsenosti v Mníchove, Budapešti a Paríżi a kuruckou témou boli obzvlášt' zaujatí. Bez ohl'adu na štýl jednotlivých malieb, Rákociho podoby sa opierali o jeho dobové stvárnenia zachované na minciach, knižných ilustráciách a olejomal'bách. ${ }^{40}$ Rákociovská téma sa vtedy objavila aj $\mathrm{v}$ ranej tvorbe českého maliara Mikoláša Aleša. ${ }^{41}$ Rákociho pochod namal'oval ako vylúčený študent akadémie pre mecéna umenia a statkára Alexandra Brandejsa; prípravnú kresbu vytvoril v roku 1876 a olejomal'bu 1877.

Tak ako Stetka, Révész a Éder, aj Dudits vyšiel z Benczúrovej školy. V Uhorsku to bola určitá záruka umeleckej spôsobilosti. Dudits v nej završoval svoje umelecké vzdelanie v rokoch 1891 až 1897. Základy získal v rodnej Pešti u starého učitel’a kreslenia Luigiho/Lajosa Rostagniho, ${ }^{42}$ ktorého pre neho odporučil maliar Orlai Petrich. ${ }^{43}$ Potom študoval na viedenskej akadémii u Christiana Griepenkerla, freskanta a majstra historických výjavov, Augusta Eisenmengera, špecialistu na monumentálnu mal’bu, a Siegmunda L'Allemanda, maliara bojových scén a koní. Po dvoch rokoch, 18. 10. 1887, sa zapísal na mníchovskú akadémiu, najprv študoval v Naturklasse u Johanna Caspara Hertericha a potom u profesora Geschichtsmalerei Alexandra Liezen-Mayera. Zánrovým výjavom, na ktoré sa spočiatku zameral, sa podučil v mníchovskej súkromnej škole Simona Hollósyho (Simiona Corbua) ${ }^{44}$. Debutoval v Mníchove v roku 1890. ${ }^{45}$ Dudits chcel íst' k Munkácsymu do Paríža, ale ten mu odpísal, že pre mladého umelca je lepšie zostat' v Mníchove, kde nie je vystavený tol'kým

múzeum, Sárospatak; Július Štetka (*1855 Králova Lehota, Liptovská župa - †1925 Budapešt'): František II. Rákoci, 1905, olej, plátno, reprodukcia in Rákóczri Album. II. Rákóczi Ferenc és kurucai. Budapest 1907, s. 142; Imre Révész (1859 Sátoraljaújhely, Zemplínska župa - †1945 Vynohradiv, Ugočská župa, Ukrajina) (podla Ádáma Mányokiho): František II. Rákoci, 1907, olej, plátno; Július Éder (*1875 Košice - †1945 Budapešt'): František II. Rákoci na bielom koni, 1909 , olej, plátno, 290 x 229 cm, pôv. pre košickú radnicu, VSM Košice - Expozícia Rodošto, (inv. č. S 2661). Rákóczi emlékkönyv I. Ed.: LUKINICH, I. Budapest 1934, s. 19 (Elek de László).

38 *1867 Brad, Huňadská župa - †1912 Vințu de Jos, župa Alba.

39 *1856 Uhrovec, Trenčianska župa - †1910 Budapešt'.

${ }^{40}$ Daniel Warou: Pamätná minca s Rákociho portrétom v profile, razená v roku 1703 v Kremnici. GALAVICS, G.: Daniel Warou (1674-1729): Emlékérem a Rákóczi-szabadságharc vallásbéke-törvényére. In: Európa sæínpadán. Ed.: MAROSI, E. Budapest 2009, s. 137-138; NOVOTNÝ, V.: Mince Josefa I. 1705 - 1711 a Františk a II. Rákocibo 1703 - 1711. Hodonín 2003. Rákociho detské portréty od neznámych autorov sú reprodukované in KAMPIS, A.: II. Rákóczi Ferenc arcképeiről. In: Rákóczi emlékekönyv II. Ed.: LUKINICH, I. Budapest 1935, s. 73 (4-ročný Rákoci) a s. 75 (8-ročný Rákoci). Bustový portrét $\mathrm{v}$ brnení je na frontispise knihy Histoire des revolutions de Hongrie, ktorú vydal Jean Neaulme 1739. Dobové portréty: David Richter st.: František II. Rákoci, olej, plátno, oválny bustový portrét z roku 1704 v MNM v Budapešti; Ádám Mányoki: František II. Rákoci, olej, plátno, bustový portrét

z roku 1712 v MNG v Budapešti (inv. č. 6001). BUZÁSI, E.: Ádám Mányoki (1673-1757). Budapest 2003, s. 288-289. K ikonografii Rákociho portrétov KAMPIS 1935, c. d. (v pozn. 40), s. 71-90. V napoleonskej dobe, v roku 1812, vytvoril Rákociho bustový portrét v brnení maliar Johann Tobias Kärling (*1780 Augsburg - †1845 Pešt').

${ }^{41} * 1852$ Mirotice, Písecko - †1913 Praha.

42 *1818 Rím - †1886 Budapešt’.

${ }^{43}$ Orlai Petrich bol pacient Duditsovho otca.

44 *1857 Sighetu Marmației, Marmarošská župa -†1918 Tiachiv, Marmarošská župa, Ukrajina.

${ }^{45}$ Rané Duditsove diela: pred 1890: Lovas párbaj (Jazdecký súboj), olej, 48 x 66 cm, súkr. maj.; 1890: Klinikai ambulatórium (Na klinike), obraz mal Munkácsy vo svojom ateliéri v Paríži; Rendeló órában (V úradných hodinách); Vasárnap délután (Nedel'né popoludnie); 1892: Portrét Józsefa Képessybo (starébo otca), olej, 80 x 60 cm, súkr. maj.; Ave Mária; A nagymama neve napja (Meniny starej mamy); Budapest-ábrázolások (Pohl'ad na Budapešt'); 1893: Plénparád (Sprievod), olej, obraz kúpil cisár do Královského paláca na Budínskom hrade, kde bol do 1912, ked' ho daroval velitel'stvu; Lánykérés/Döntö pillanat (Pytačky/Rozhodujúci okamih), olej, plátno, 104 x $82 \mathrm{~cm}$, SNG Bratislava, inv. č. O 467; 1894: Sv. Štefan král, oltárny obraz, Recsk, Hevešská župa, objednávatel' egerský/jágerský arcibiskup Jozef Samaša/József Samassa; 90. roky: Ruiny kostola v Araŭi (pri Novom Bečeji), olej, 90 x 72 cm, súkr. maj.; Dunajpri Želeaných vrátach, olej, 30 × 33 cm, súkr. maj. Niektoré obrazy spomína REISZ 2018, c. d. (v pozn. 8), s. 373. 
pokušeniam menit' štýl mal'by. ${ }^{46}$ Dudits išiel do Talianska a potom sa vrátil do Budapešti. Počas štúdia u Benczúra namal'oval v roku 1895 monumentálny obraz o znovu pripojení Fiume (Rijeky) k Uhorsku. Bol určený do tamojšej radnice. ${ }^{47}$ Dudits sa dostal do širšieho povedomia po získaní štátnej objednávky na výzdobu chodieb novej budovy uhorského parlamentu, dielo architekta Imre Steindla. Na monumentálnych mal'bách začal pracovat' v roku 1897. Zvečnil Korunovačnú prísahu Františka Jozefa I. v Budine a vytvoril kompozície reprezentujúce jednotlivé ministerstvá: Národnú obranu, Spravodlivost', Náboženstvo a Školstvo, Polnohospodárstvo, Remeslá a Obchod. ${ }^{48}$ Pri ich tvorbe sa odklonil od dovtedajšieho štýlu a začal uplatňovat' výrazné kontúry a lokálne farby. $\mathrm{Na}$ jednej strane ho obmedzovala neogotická architektúra, na druhej strane ho lákala vládnuca secesia.

Dudits sa secesnému štýlu oddal pri návrhoch na mozaiky pre fasádu obytného domu zamestnancov pivovaru Antona Drehera ml. v Kőbányi (na Népszinház utca 22), ktorý v roku 1906 naprojektoval Emil Vidor, alebo pri návrhoch na mozaiky pre arkády Kerepešského cintorína (na Fiumei út 16), postavených v rokoch 1904 až 1908 podl’a projektu Lajosa Gerleho a Ármina Hegedüsa. Tu už Dudits spolupracoval s mad’arskými nadšencami preraffae-

\footnotetext{
${ }^{46}$ ÉBER, L.: Dudits Andor. In: Müvészet, 10, 1911, č. 10, s. 397-403.

${ }^{47}$ Andor Dudits: Navrátenie Fiume Uborsku, 1895, olej, plátno, Námornícke a historické múzeum Rijeka (inv. č. PPMHP 1773/a). Múzeum vlastní aj skicu k obrazu (inv. č. PPMHP 1773/b). Reprodukcia obrazu in MARCZALI, H.: Magyarorsqág története III. Károlytól a bécsi congresszusig 1711 - 1815. A magyar nemzet története. Budapest 1898, obr. po s. 308. Dostupné online: http://mek.oszk.hu/01900/01902/html/ index173.html). Obraz pripomína Corpus separatum - akt, ktorým Mária Terézia v roku 1776 vyňala Fiume spod priamej správy Rakúska a pričlenila ho k Uhorsku. Zachytáva starostu mesta ako jasajúcim občanom číta list od cisárovnej.
}

${ }^{48}$ REISZ, C. T.: Dudits Andor festőművész emlékezete. In: Magyar nemzeti léveltár. Dostupné online: http://mnl.gov.hu/ $\mathrm{mnl} / \mathrm{ol} /$ hirek/dudits_andor_festomuvesz_emlekezete), publ. 10. 6. 2016; SISA, J.: Az Országház. In: HERMANN, R. et. al.: A Magyar Országgyúlés. Budapest 2011, s. 103-118 (tu s. 115); DÖMÖTÖR, I.: Az új Magyar országháza falfestményei. In: Müvészet, 1, 1902, č. 3, s. 153 a nasl.

49 *1865 Pešt' - †1944 Budapešt'. lizmu. Mozaiky totiž realizoval umelecký sklár Miksa Róth ${ }^{49}$, obdivovatel' Williama Morrisa a Edwarda Burne-Jonesa, popredných umelcov druhej generácie preraffaelistov. Na výzdobe parlamentu aj arkád cintorína bol jeho kolegom maliar Aladár Körösfői-Kriesch ${ }^{50}$, vtedy známy aj ako autor knihy Ruskinról $s$ az. Angol praerafaelitákról (O Ruskinovi a anglických preraffaelistoch), ktorú vydal v roku 1905. Vplyv anglických estetických názorov bol v uhorskom prostredí citel'ný od 90. rokov 19. storočia, kedy sa tvorba prvých preraffaelistov začala uzatvárat'. Povolaním učitel'ka Šarlota Geőcze de Szendrō preložila Ruskinovu knihu o benátskej architektúre a potom napísala o ňom velebiacu knihu (1903). ${ }^{51}$ O preraffaelistoch písal publicista István Dömötor (1904) a historik umenia István Supka (1905). Navyše v Budapešti sa dali zohnat' ich knihy a reprodukcie ich diel. ${ }^{52} \mathrm{Na}$ jeseň 1895 a na jeseň 1900 vystavoval v Múcsarnoku Walter Crane ${ }^{53}$ stovky svojich kresieb, ilustrácií a grafík. Pri príležitosti druhej výstavy, ktorá bola samostatná, prišiel do Budapešti osobne aj s rodinou. ${ }^{54}$ Bola to vítaná príležitost' oboznámit' sa s týmto poeticky ladeným stúpencom preraffaelistov a popredným predstavitel'om hnutia Arts \& Crafts, ktoré viedol Morris a Ruskin. Medzi exponátmi prvej výstavy bola aj Cranova grafika jeho obrazu - Most

$50 * 1863$ Budín - †1920 Budakeszi.

${ }^{51}$ RUSKIN, J.: Velencze kövei (The Stones of Venice). Budapest 1896; GEÖCZE, Sarolta (*1862 Bačkov, Zemplínska župa - †1928 Budapešt'): Ruskin élete és tanitása (Život a učenie Ruskina). Budapest 1903. Túto ilustrovanú knihu zmieňuje PÉTERI, É.: Pre-Raphaelitism in Hungary. In: Worldwide Pre-Raphaelitism. Ed.: TOBIN, T. J. New York 2005, s. 185-214 (tu s. 188-189).

52 PÉTERI 2005, c. d. (v pozn. 51), s. 189-190.

53 *1845 Liverpool - †1915 Horsham, Anglicko. Bližšie o autorovi O'NEILL, M.: Walter Crane: The Arts and Crafts, Painting, and Politics. New Haven - London 2010.

${ }^{54}$ Sprostredkovatel’om výstavy bol herec a novinár Kálmán Rozsnyai, ktorý bol v Anglicku Cranovým host'om a vzbudil u neho záujem o Uhorsko. V Anglicku strávil dlhš́ čas aj Jenő Radisics, prvý riaditel' Múzea umeleckých remesiel; medzi jeho prvé akvizície patrili látky z tvorby Williama Morrisa. Radisics bol kurátorom výstavy Britské umelecké remeslo, ktorá sa konala od septembra do novembra 1902. PÉTERI 2005 , c. d. (v pozn. 51$)$, s. 186-187. 


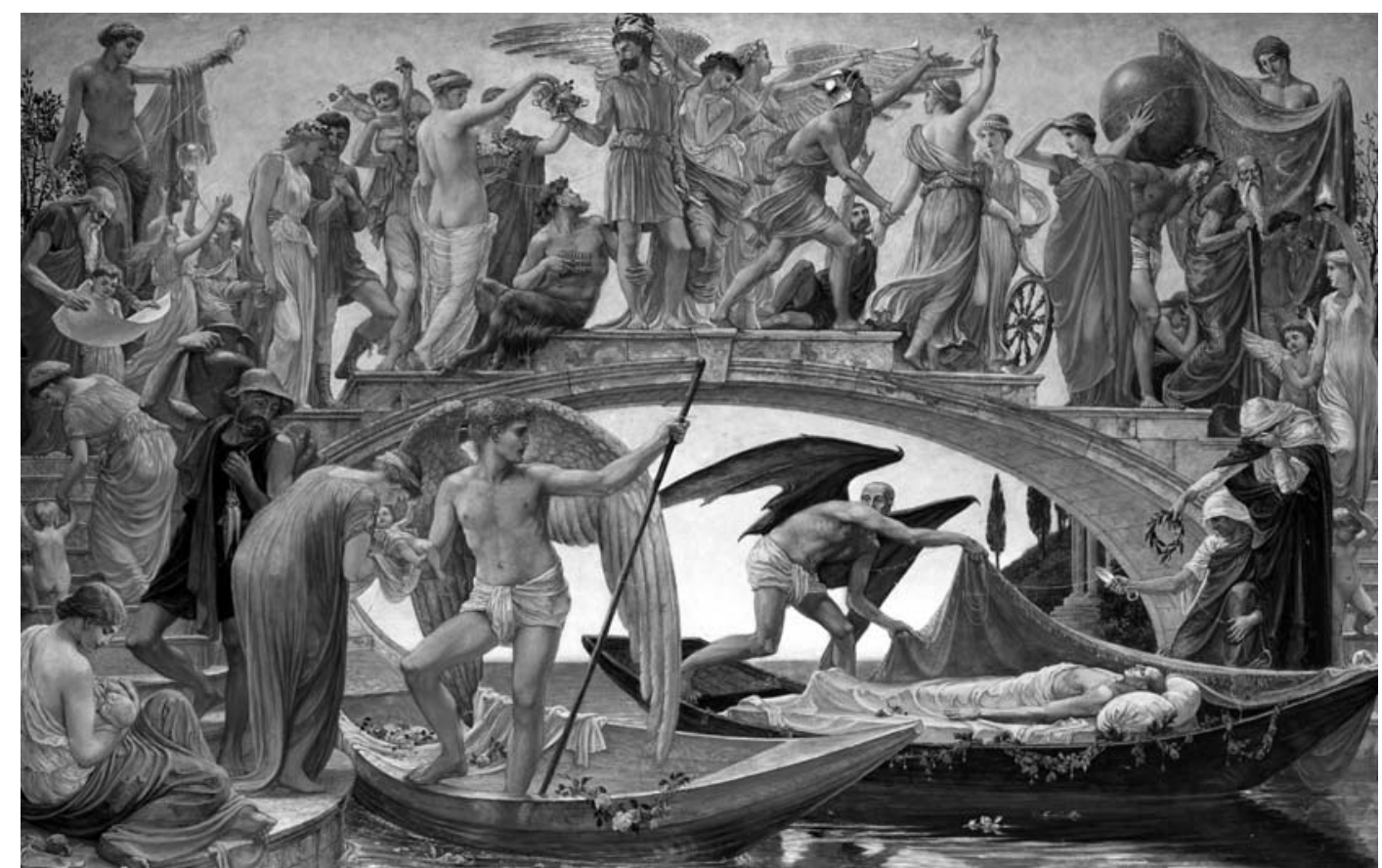

Obr. 3: Walter Crane: Bridge of Life, 1884, olejomal'ba na plátne, súkromný majetok. Zdroj: https:// commons.wikimedia.org/wiki/File:Walter_Crane_-_The_Bridge_of_Life_(1884).jpg

života (Az élet hídja), reprodukovaná vo Vasárnapi Ujság. ${ }^{55}$

Cranova olejomal'ba The Bridge of Life je $\mathrm{z}$ roku 1884. Nachádza sa v súkromnej zbierke. Symbolickým a trochu ironickým spôsobom zachytáva pút' človeka. Anjel s vel'kými farebnými krídlami prichádza po rieke na člne zdobenom ružami a podáva žene novonarodené diet'a. Matka ho kojí, pri nohách má klbko nite (osudu). Muž-živitel’ nesie džbán na pleci, ryby v ruke a chlieb na chrbte. Žena-matka opatrne vedie diet'a po stupňoch smerom hore. Tam čaká starý učitel' a ukazuje už vyrastenému chlapcovi písomnosti. Pod postavou moiry (sudičky) namotávajúcej nit' života sa hrajú deti, vyfukujú mydlové bubliny (znak pominutel'nosti). Na d'alšom stupni si mladý muž vedie nevestu $\mathrm{v}$ prítomnosti Venuše (lásky). $\mathrm{Na}$ najvyššom stupni stojí zrelý muž, dolu ho za nohu

\footnotetext{
${ }^{55}$ PRÉM, J.: A Walter Crane-féle kiállítás a Műcsárnokban. In: Vasárnapi Ujság, 42, 1895, č. 43 (27. 10.), s. 711-712, obr. na s. 712. K výstave vyšiel katalóg ISOZ, E.: Walter Crane. Budapest 1895. Pozri aj GÁL, I.: Walter Crane in Hungary. In: The New Hungarian Quarterly, 19, 1965, s. 219-221; KESERÜ, K.: Art
}

drží Faun (vášeň), vedl’a neho je žena s vavrínovým vencom (úspech), Fáma trúbi (na slávu), Hermes (obchod) naháňa ženu s mešcom (bohatstvo). O stupeň nižšie stojí Fortúna s vrtkavým kolesom št'astia. Pod postavou rozprestierajúcou drapériu s večernou oblohou je starec, nesie zemegul'u na chrbte (t'archu sveta), potom sa zhrbený opiera o palicu a mladíka-pokračovatel'a rodu, ktorý si ide odhryznút' z jablka (asi na znak dedičného hriechu). Starec nasleduje ženu držiacu plameň večného svetla, ktorá kráča pred ním. Na poslednom schode smútiaca žena hádže vavrínový veniec a moira prestriháva nit' života. Muž-nebožtík leží v člne, zdobenom vlčími makmi a anjel smrti s čiernymi netopierími krídlami ho po rieke odváža preč, do chrámu (večnej pamiatky), ktorý stojí na brehu v pozadí. Na okrajoch obrazu sú ovocné stromy - vl'avo plodiace a vpravo odumierajúce.

Contacts between Great Britain and Hungary at the Turn of the Century. In: Hungarian Studies, 6, 1990, 2, s. 141-153 (o Cranovi s. 144, 150); GELLÉR, K.: English Sources of „Hungarian Style“. In: Britain and Hungary I. Ed.: EMYEY, G. Budapest 1999, s. 17-29. 


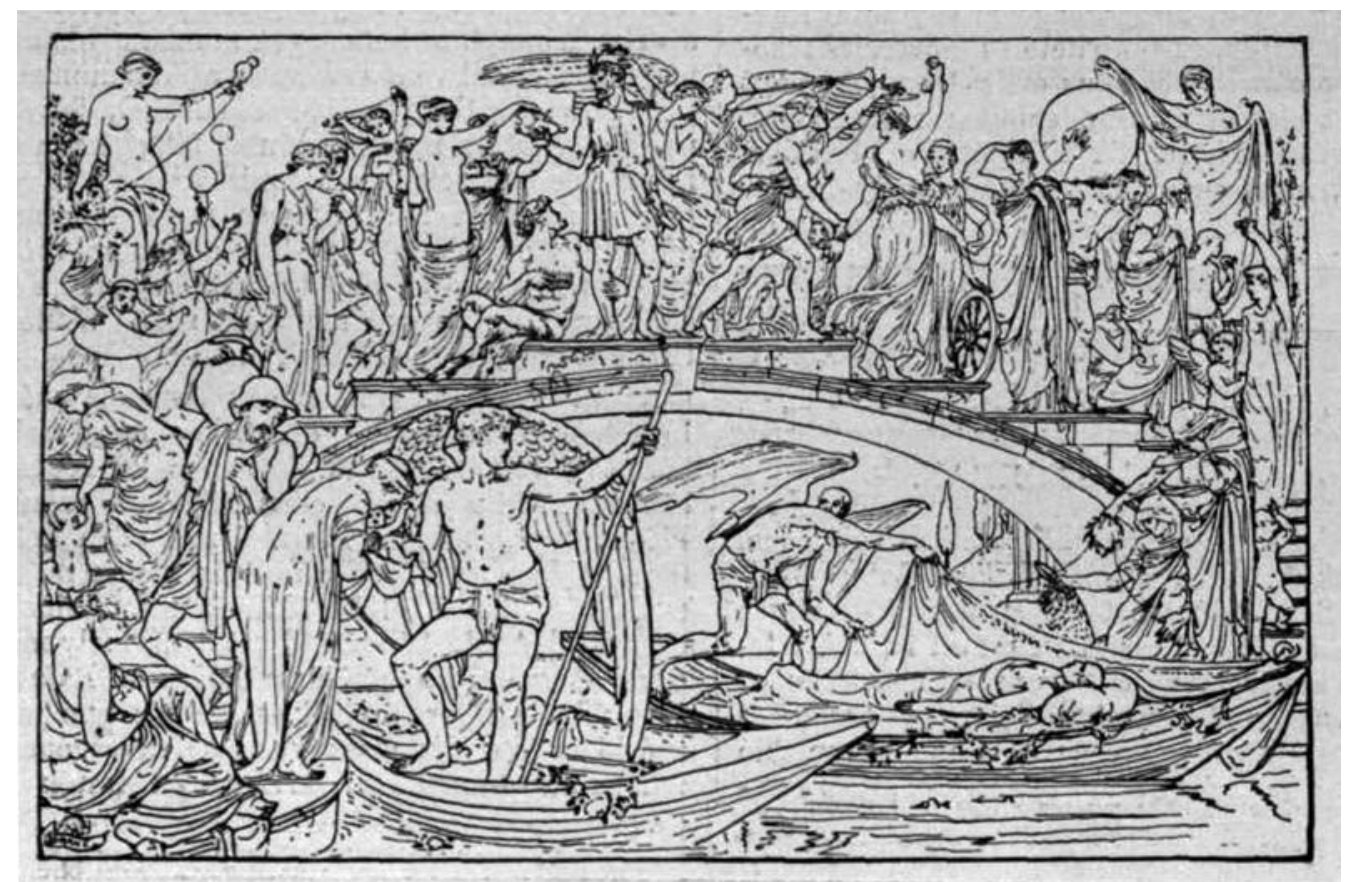

Obr. 4: Walter Crane: Bridge of Life, okolo 1884, drevorez na papieri, vystavený v Mücsarnoku. Repro z. Vasárnapi Ujság 27. 10. 1895 , s. 712.

Koncept a kompozíciu Cranovho Mosta života Dudits zopakoval pri tvorbe svojej košickej mal'by a priradil sa tak $\mathrm{k}$ tvorcom tohto ikonografického

\footnotetext{
${ }^{56}$ Idea delit' ludský život na etapy je známa od antiky. Solón (ca 600 pred n. 1.) hovoril o desiatich etapách po siedmich rokoch, Hippokrates (ca 400 pred n. 1.) o siedmich a Aristoteles (ca 350 pred n. l.) o troch: mladosti, zrelosti a starobe. V De Lisleho žaltári (ca 1310, British Library, Londýn) je Koleso desiatich fáz života muža (f.126v). Kolorovaný drevorez z roku 1482 od neznámeho autora (Die zehen eygenschaft des altters der menschen, British Museum, inv. č. 1872,0608.351) zobrazuje muža od narodenia po smrt' (v hornej línii), ku každej fáze života je priradené zviera (v dolnej línii). Okolo 1540 vytvoril augsburský kresliar Jörg Breu Jr. a amsterdamský rytec Cornelis Anthonisz. drevorez (v Herzogliches Museum Gotha), na ktorom sú už fázy života muža zobrazené na stupňoch, pod každým je príslušné zviera, na vrchole číha smrtka. Toto dielo sa považuje za ikonografický základ d'alších zobrazení. Cornelis Antonisz. vytvoril ešte jeden drevorez na túto tému (De Trap des Levens, medzi 1543-1553, Rijksmuseum, inv. č. RP-P-1886-A-10296). Ked’že l’udia sa obvykle nedožívali vyššieho veku, zobrazenia tohto typu boli zriedkavé. Bežnejšími sa stali od 17. storočia. Postupne sa z nich vytrácali zvieratá. Stupne života žien a párov sa zobrazovali od osvietenstva (Baltasar Talamantes, 1766-1805: La escala de la vida, Institu-
}

modelu, ktorý sa vo výtvarnom umení rozvíjal od stredoveku. ${ }^{56}$ Dudits neraz čerpal z rovnakých zdrojov inšpirácií ako protagonisti Umeleckej koló-

to Municipal de Historia, Barcelona; Winter Carl Hansson: Alderstrappan, 1799, Bingsjö, Švédsko; Gustaf Otto Wasenius: Stupne života, 1831, drevorez, Kodaň). Stupne života dosiahli vrchol popularity $\mathrm{v} 19$. storočí, boli vd’ačným námetom obrazového priemyslu. $V$ ňom sa uplatnil napr. schwarzwaldský maliar hodín Fridolin Leiber $(* 1853$ Niedereschach - †1912 Frankfurt am Main), ktorý od roku 1881 pracoval pre frankfurtské vydavatel'stvo Eduarda Gustava Maya. Mal'oval sväté obrázky, ale jeho stvárnenie Lebensaltersstufen, Die Stufenalter der Frau a Die Stufenalter des Mannes sa predávali masovo. V medzivojnovom období takéto zobrazenia ustali. Z tohto pohl'adu patril Dudits k posledným umelcom, ktorí siahli po tomto modeli. ENDREß, F.: Bilder des Alterns und der Lebensalter im Bildraum Erwachsenenbildung. Springer-Verlag 2019, s. 155 a nasl. (Breu), s. 159 a nasl. (Antonisz.), s. 165 a nasl. (Leiber); LUCKE, Ch. - LUCKE, M. - GOGOL, M.: Lebenstreppen - oder wie man den Alternsprozess über die Jahrhunderte gesehen hat. In: European Journal of Geriatrics, 11, 2009, č. 3-4, s. 132-140; EHMER, J.: Die Lebenstreppe. In: Ensyklopädie der Neuzeit 7. Ed.: JÄGER, F. Stuttgart - Weimar 2008, s. 50-55; EHMER, J.: Die Lebenstreppe. Altersbilder, Generationsbeziehungen und Produktionsweisen in der 


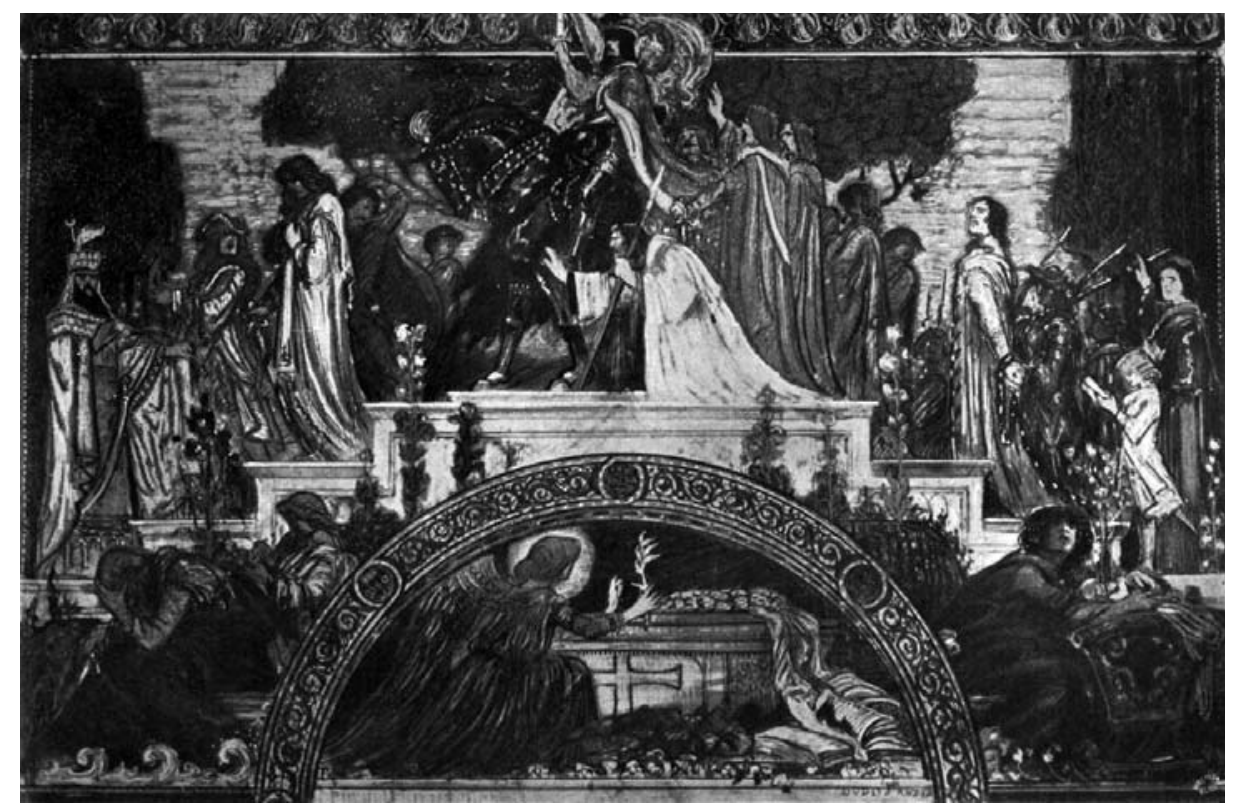

Obr. 5: Andor Dudits: Náurh pamätného triptychu Františkea II. Rákociho (stredná a dolná cast'), kresba na kartóne. Repro z. Müvészet 1912, c.. 9, s. 338 (náurh je zrkeadlovo otočený).

nie v Gödöllő, ktorí koncepčne rozvíjali umelecké postuláty preraffaelistov, hnutia Arts \& Crafts, ako aj generačne starších nazarénov. ${ }^{57}$

Dudits mal už pred košickou mal'bou skúsenosti s mal'bami v kostolných interiéroch. Do sakrálneho maliarstva vnášal secesné a symbolistické prvky, čo bolo do určitej miery výnimočné, ked’že cirkevní hodnostári sa modernizmom bránili; prijatel'nejšie

europäischen Neuzeit. In: Formen familialer Identität. Ed.: EHALT, H. Ch. Wien 2002, s. 53-85 (tu s. 53-64); BRÜCKNER, W.: Kunst und Konsum - Massenbilderforschung. Würzburg 2000, s. 407-444 (kap. Kleinbürgerlicher und wohlstandsbürgerlicher Wandschmuck im 20. Jahrhundert); https://publicdomainreview.org/collections/the-steps-of-life/, cit. 2.8.2019.

${ }^{57}$ Pozri ELLIS, M. et al.: Victorian radicals : from the Pre-Raphaelites to the arts \&o crafts movement. Munich 2018; PÉTERI 2005, c. d. (v pozn. 51); GELLÉR, K.: A gödöllöi müvésztelep -1901-1920. Gödöllői Városi Múzeum 2001; KERESÜ, K.: The Workshops of Gödöllő: Transformations of a Morrisian Theme. In: Journal of Design History, 1, 1988, č. 1, 1-23. Kolóniu založil Körösfői-Kriesch s donáciou ministerstva 1901; pomáhal mu pritom jeho švagor Sándor Nagy. Zoznámil sa s ním v Ríme 1891 u nazaréna Ferenca Szoldatitsa. boli pre nich nazarénske produkty stojace na starých (renesančných) inšpiráciách bez náznakov (barokovej) zmyselnosti. Ked' Dudits v roku 1908 mal'oval v secesnom mode oltárny obraz Navstívenie Panny Márie pre vojvodinskú obec Bačka Topola, použil síce tempery, ${ }^{58}$ ale štýl až tak neprispôsobil ani juhotirolskému neogotickému oltáru, ani neogotickej architektúre kostola - Crkevy sv. Bogorodice sa srpom. ${ }^{59}$ To platí aj

Nagy strávil niekol'ko rokov v Paríži, objavil preraffaelistov, videl ich vel'kú výstavu a spoznal nimi ovplyvnenú skupinu rosekruciánov; výrazne ho ovplyvnil Walter Crane. 1895 ho v Parízi navštívil Körösfői-Kriesch a Nagy zas jeho v Sedmohradsku, kde sa zaoberali ludovým umením, d’alším zdrojom ich inšpirácií. Körösfői-Kriesch bol budapeštianskym starším spolužiakom Jozefa Hanulu (*1863 Liptovské Sliače - †1944 Spišská Nová Ves). HERUCOVÁ, M.: The Interest in the Art of the Nazarenes in Slovakia. In: Forum Historiae, 11, 2017, č. 2, s. 47-61 (o Szoldatitsovi s. 56-58); ŐRINÉ NAGY, C. et al.: Körösföi-Kriesch Aladár (1863-1920) festó- és iparmüvész. monográfiája és oeuvre katalógusa. Gödöllői Városi Múzeum 2016; PÉTERI 2005, c. d. (v pozn. 51), s. 195; HANULA, J.: Spomienky slovenského maliara. Martin 1940, s. 151.

${ }^{58}$ REISZ 2018, c. d. (v pozn. 8), s. 373. 


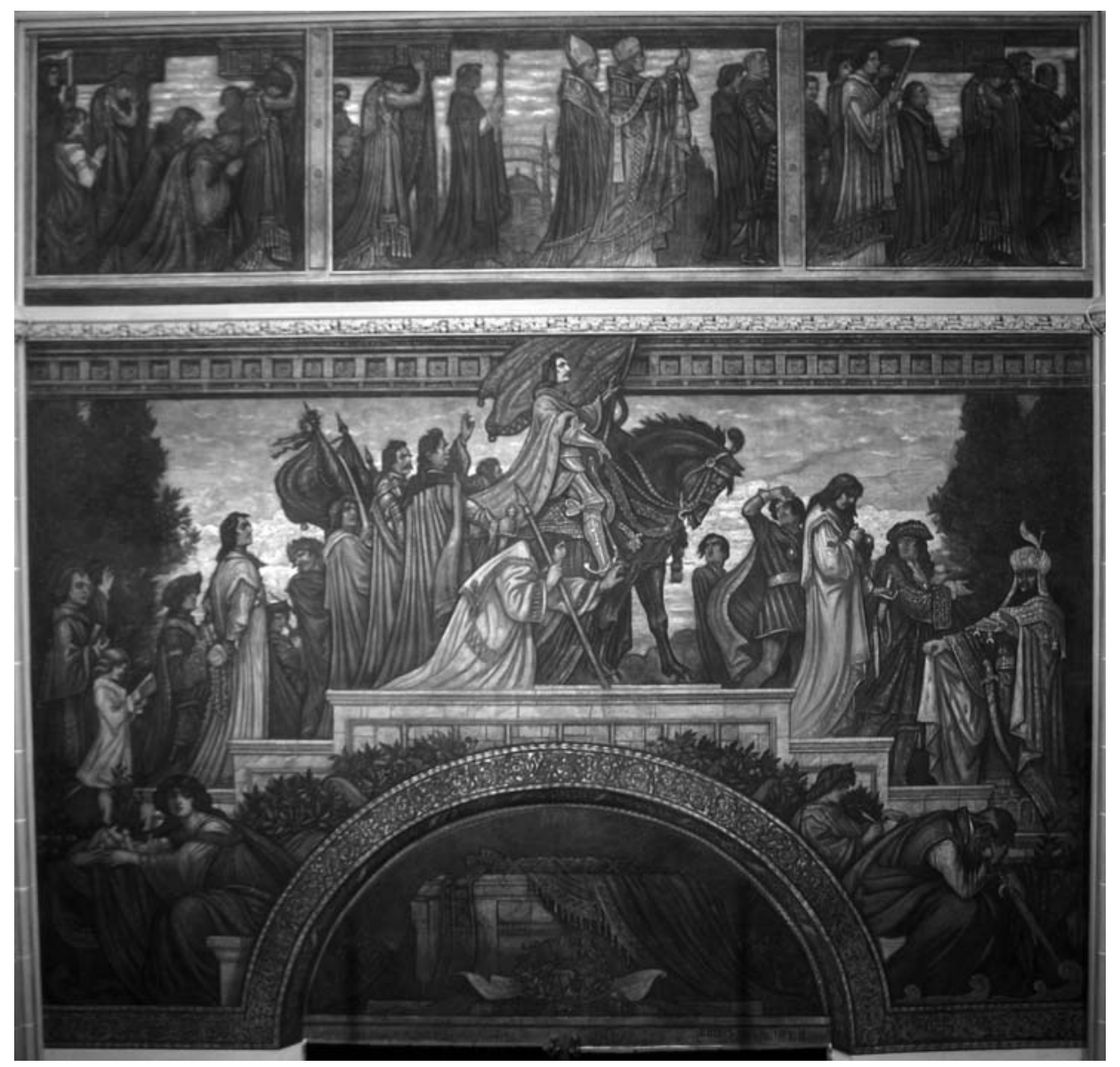

Obr. 6: Andor Dudits: Pamätný triptych Františke II. Rákociho, 1914 - 1916, nástenná malba, Dóm sv. Aľ̌bety, Košice. Foto: (C) Peter Gomboš.

pre šest' nástenných malieb pre barokovo-klasicistický Kostol Nanebovzatia Panny Márie v Brezne, na Horehroní, kde v roku 1909 vláčnymi líniami, lokálnymi farbami a prírodnými komponentmi štylizovaných stromov a kvetov namal'oval vo svätyni sv. Śtefana král'a a sv. Ladislava, v lodi Narodenie a Ukrižovanie

\footnotetext{
${ }^{59}$ Kostol bol postavený v rokoch 1904 - 1906. Jeho donátormi boli gróf Ján Nepomuk Zichy a jeho manželka barónka Irma, rod. Kray z Krajova a Topola. REISZ 2018, c. d. (v pozn. 8), s. 373 .

${ }^{60}$ O udalosti KOČí, M.: Vzt’ah uhorských král'ovien k svojim venným mestám v stredoslovenskej banskej oblasti. In: Forum Historiae, 2, 2008, č. 1, s. 1-7. Nástenná mal'ba je niekedy mylne interpretovaná ako udalost' z 13. 6. 1405, ked' Žigmund udelil
}

a pri vchode dva historické výjavy: vl’avo L'udovita I. Vel'kébo z rodu Anjou ako prichádza do Brezna spolu so svojou manželkou Elizabetou Kotromanić, aby ho povýśil na mesto [15. augusta 1380] a vpravo Žigmunda Luxemburskébo ako dáva Brezno do vena svojej druhej manželke Barbore Celjskej [22. mája 1424]. ${ }^{60}$

breznianskemu farárovi Jánovi z Hybe a jeho nástupcom právo vyberat' dežmu (desiatok) v Brezne a osade Pavlova (Hronec) a túto užívat' v prospech farnosti. Okrem toho Žigmund 14.1.1404 oslobodil obyvatel'ov mesta od pridaných poplatkov a pridružil ho k ostatným banským mestám a 8. 9 . 1406 dal miestny mlyn do majetku mesta. Duditsove návrhové kresby štyroch breznianskych malieb publikoval ÉBER 1911, c. d. (v pozn. 46): Sv. Ladislava, Narodenie, Ludovita I. Vel'kébo a Žigmunda Luxemburského. 


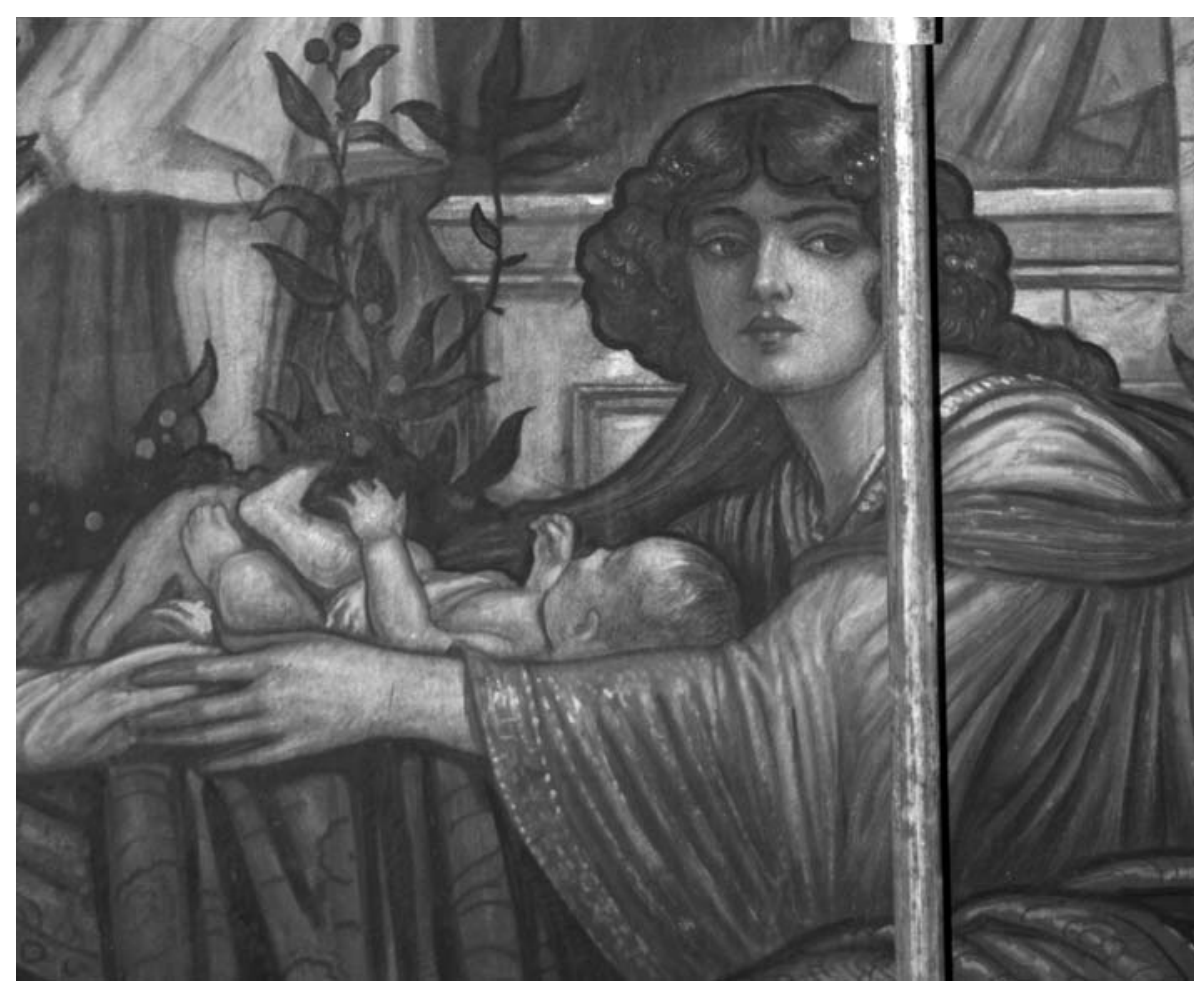

Obr. 7: Andor Dudits: Helena Zrínska, detail Rákociho triptychu, 1914 - 1916, nástenná malba, Dóm sv. Alǐbety, Košice. Foto: (C) Peter Gomboš

Sút’až na košickú mal'bu, ktorú Dudits vyhral, mala podl'a predstáv komisie a jej pokynov dotvorit' severnú stenu transeptu, 13,5 m vysokú a $8,5 \mathrm{~m}$ širokú, s tým, že sa bude rešpektovat' jestvujúce architektonické členenie a severný portál. ${ }^{61}$ Mal'ba mala vystihovat' osobnost' Františka II. Rákociho a zvečňovat' pamiatku nielen na neho, ale aj na jeho druhov. Zároveň mala umocňovat' atmosféru gotického chrámu, ale nie natol'ko, aby nezohl'adňovala barokovú dobu, v ktorej Rákoci žil. ${ }^{62}$ Komisia

\footnotetext{
${ }^{61}$ Na tejto stene bola freska Premenenie Pána, ktorú podl’a Raffaela namal’oval Ignác Klimkovits/Klimkovič v roku 1863. Pri regotizácii dómu bola odstránená. WICK, B.: Kassa története és múemlékei. Kassa 1941, s. 303.

${ }^{62}$ ÉBER, L.: A Rákóczi-freskó. In: Müvésæet, 11, 1912, 9, s. 331 339 (www.mke.hu/lyka/11/331-339-rakoczi.htm); MÁRKI, S.: Rákóczi legendája és története (Felolvasta a szakosztály 1911 februárius 22-iki ülésén a szerző). In: Erdélyi Múzeum, $28,1911,4$, s. 221
}

oslovila desiatich maliarov, z ktorých sa dvaja, Aladár Körösfői-Kriesch a Július Éder, sút’aže nezúčastnili. Ostatní až na Duditsa a Sándora Nagya boli odchovanci Bertalana Székelya ${ }^{63}$ na tzv. Mintarajziskola. Dezső Kölber ${ }^{64}$ vo svojom návrhu rozdelil stenu na tri polia, orámovanie vytvoril $\mathrm{v}$ neogotickom štýle a figurálne výjavy v neobarokovom, čo na komisiu pôsobilo disharmonicky. Sándor Novák ${ }^{65}$ postupoval podobne. Rezső Raksányi ${ }^{66}$ volil ornamentálnu kompozíciu na červenom podklade, ktorý podla

63 *1835 Cluj-Napoca, Sedmohradsko - †1910 Budapešt'-Mátyasföld. Bližšie o maliarovi BAKÓ, Z.: Székely Bertalan. Budapest 1999.

$64 * 1874$ Budapešt' - †1945 Budapešt'.

${ }^{6}$ *1878 Debrecen, Hajducká župa - †1942 Debrecen.

${ }^{6}$ *1879 Budapešt' - †1950 Szentes, Čongrádska župa. 
neho symbolizoval Rákociho utrpenie. Octavian Smigelschi, ${ }^{67}$ sedmohradský umelec a potomok pol'ského šlachtického rodu, ktorý v rokoch 1890 až 1891 pôsobil ako učitel' kreslenia v Banskej Štiavnici, narazil na kritiku komisie, jeho návrh sa zdal napriek nepochybným kvalitám a pozoruhodnej farebnosti príliš teatrálny. Viktor Tardos Krenner ${ }^{68}$ zvolil ako leitmotív vlajúcu zástavu, na koni cválajúci Rákoci s vytaseným mečom na ňu ukazoval a zhromaždený klérus ju posväcoval. (Poukazovalo to na jednu zo zástav s nápisom Cum Deopro Patria et Libertate/S Bohom za vlast' a slobodu, ktoré Rákoci zadovážil vo Francúzsku a poslal do Královského Uhorska). Zsigmond Vajda (Weiss), ${ }^{69}$ ktorého mecénom bol istý čas gróf Emanuel Andrássy z Betliara, ponúkol takisto neobarokový obraz $\mathrm{v}$ neogotickom ráme. $\mathrm{O}$ priazeň poroty sa uchádzal aj Sándor $\mathrm{Nagy}^{70}$ z Umeleckej kolónie v Gödöllő. ${ }^{71}$ Jeho idea mala priam mystický charakter - Rákoci vystupoval ako potomok stredovekých rytierov hladajúcich svätý grál. Podl'a komisie to úplne nevystihovalo jeho osobnost', ocenila však jemne štylizované postavy klačiacich anjelov a uhorských svätcov.

Andor Dudits k svojmu návrhu iba vecne poznamenal, že stenu poňal ako monumentálnu pamätnú tabul'u a kvôli jej členitosti ju horizontálne rozdelil na tri časti - hornú, strednú a dolnú. ${ }^{72}$ Do strednej, plochou najväčšej, situoval klúčové momenty Rákociho života. Začínajú vl’avo dolu ${ }^{73}$ narodením - Helena Zrínska/Jelena Zrinska, po prvom manželovi Rákoci a po druhom Tököli, sedí nad kolískou a chráni $\mathrm{v}$ náručí malého Františka. ${ }^{74}$ Ďalšie výjavy namal'oval Dudits ,"na moste života“ - na stupňoch oblúku, tri stúpajú hore na vrcholné plató a tri klesajú dole. Po stvárnení narodenia je Rákoci (na prvom vyššom stupni) ako dospievajúci

\footnotetext{
67 *1866 Ludoș, Sibiňská župa - †1912 Budapešt’.

68 *1866 Budín - †1927 Budapešt'.

69 *1860 Bukurešt' - †1931 Budapešt'.

70 *1869 Németbánya, Vesprémska župa - †1950 Gödöllő, Peštianska župa.

${ }^{71}$ Sándor Nagy vytvoril na Slovensku v medzivojnovom období (1923) nástenné mal’by v Kostole sv. Štefana v Trsticiach na Źitnom ostrove.
}

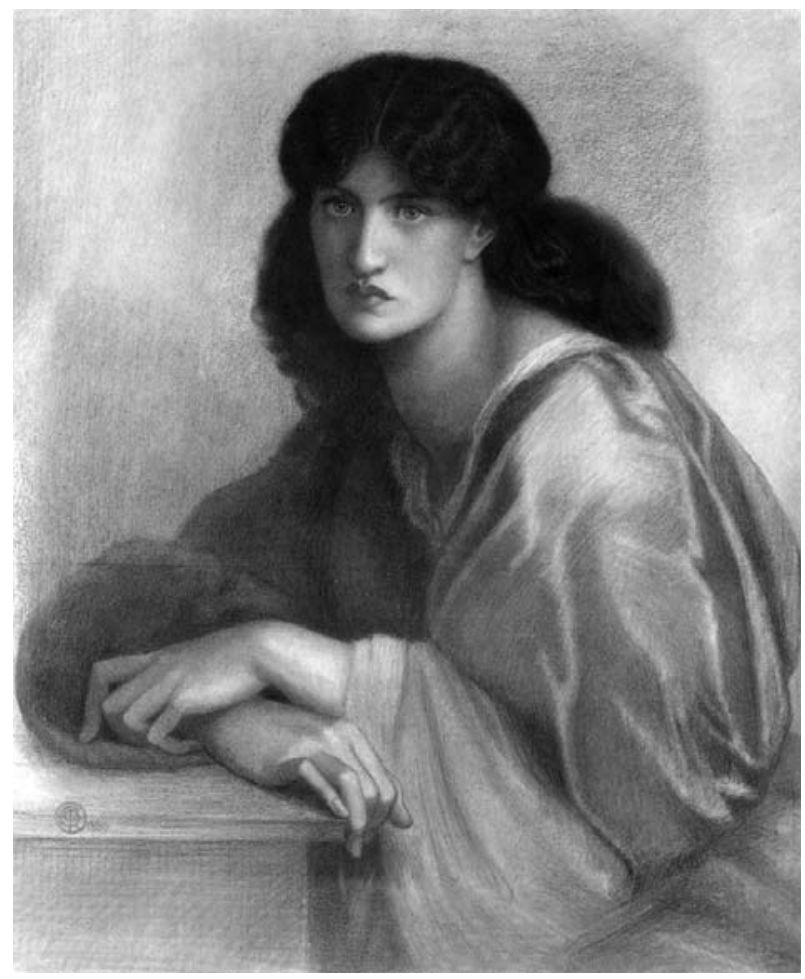

Obr. 8: Daniel Gabriel Rossetti: La Donna della Finestre (Jane Morris), 1880, kresba pastelom na papieri, súkromný majetok. Zdroj: www.the-athenaeum.org/art $/$ detail.php? $I D=25269$

chlapec s knihou v ruke a vedl'a neho viedenský arcibiskup Žigmund Kollonich/Kolonić, ktorý ukazuje na nebesia, lebo podl'a Duditsa ho naučil bohabojnosti; jemu bol Rákoci na cisársky príkaz zverený na prevýchovu, ked' mu uväznili matku (1688), (a on ho poslal jezuitom do Prahy a potom do Jindřichovho Hradca). ${ }^{75}$ Rákoci (na druhom

${ }^{72}$ ÉBER 1912, c. d. (v pozn. 62).

${ }^{73}$ Návrh, publikovaný v ÉBER 1912, c. d. (v pozn. 62), je oproti realizácii zrkadlovo otočený, nezačína vl’avo, ale vpravo.

${ }^{74}$ O Rákociho detstve písala DÁNIELNÉ LENGYEL, L.: $A$ gyermek Rákóczi. Budapest 1930.

${ }^{75}$ Bližšie NOVÁKOVÁ, S.: František Rákoczi a Jindřichův Hradec. In: Vlastivédný sborník Dačicka, Jindrichobradecka a Treboňska. Red.: PIKAL, J. Jindřichův Hradec 2006, s. 1828. Rákoci mal 12 rokov, ked' sa musel vo Viedni s matkou 
vyššom stupni) stojí hrdo, hoci má spútané ruky a odvádzajú ho do žalára vo Wiener Neustadte (1700). Zástup postáv (na tret'om vyššom stupni) predstavuje jeho druhov, s ktorými sa vzoprel proti cisárovi, ${ }^{76}$ jeho najbližší - užhorodský župan, povstalecký generál a jeho pravá ruka Mikuláš Bercsényi a povstalecký hlavný kapitán Ádám Vay sú už spolu s ním na vrcholnom plató. Rákoci je zobrazený ako panujúce knieža: sedí na koni v rytierskom brnení a v červenom plášti s hermelínom, jednou rukou drží opraty a druhou dvíha meč (na návrhu, na mal'be drží červenú zástavu). Pri koňovi je kl’ačiaca postava poddaného $\mathrm{v}$ dlhom bielom odeve (tak ako u Crana postava sediaceho Fauna); zrejme pripomína Rákociho oslobodenie poddaných, ktorí mu pomáhali v boji, preto pravou rukou drží kopiju a l'avou ukazuje na nasledujúce udalosti: Rákoci (na nižšom hornom stupni) opúšt'a vlast' v sprievode dvoch postáv, odchádza so sklonenou hlavou, ale s rukou na srdci, smeruje $\mathrm{k}$ francúzskemu královi Ludovítovi XIV. (na nižšom strednom stupni), ale ten ho gestom ruky posiela do otvorenej náruče sultána Ahmeda III. (na najnižšom stupni), ktorý mu vo svojej ríši ponúkol azyl. ${ }^{77}$ Vpravo dolu pod schodmi je posledný výjav - zostarnutý Rákoci sedí

(navždy) rozlúčit'. Vo VSM Košice sa zachoval obraz 8-ročného Rákociho, v čase výskumu v expozícii Rodošto. Podl’a predlohy z roku 1684 (KAMPIS 1935, v pozn. 40, obr. na s. 75) ho v roku 1912 namal’oval László Tatz (*1888 Máriapócs, Sabolčská župa - † pravdepodobne 1951 Filipíny). Rákoci po absolvovaní jezuitských škôl odišiel do Rekemu (v dnešnom Belgicku) za svojou sestrou Juliannou, vyd. Aspremont-Lynden z Rekemu/von Reckheim. Tam ho zoznámili s 15-ročnou Charlotte Amalie von Hessen-Rheinfels-Rotenburg, s ktorou sa v Kolíne nad Rýnom oženil (1694). Mali pät' detí: dvojčatá Leopolda-Ludovíta (*1696) a Leopolda-Juraja (*1696), synov Jozefa $(* 1700)$ a Juraja $(* 1701)$ a dcéru Šarlotu (*1706). Rákoci mal ešte s kňažnou Alžbetou Sienawskou, rod. Lubomirskou, nekorunovanou královnou Pol’ska, dcéru Máriu Žofiu (*1698).

${ }^{76}$ Vzburu pripravoval v Pol'sku na panstve Sienawskich v obci Berežani (na dnešnej Ukrajine), kam sa uchýlil po úteku $z$ väzenia vo Wiener Neustadte (1701). Tam za ním prišli jeho poddaní - obchodník so sol’ou Tamás Esze z obce Tarpa a vojenský zbeh Albert Kis z obce Barkasovo. Presvedčili ho, aby sa postavil na čelo ich povstania. L'udia totiž nevládali živit' početné cisárske vojsko rozmiestnené po krajine. Bližšie KÓNYA 2005, c. d. (v pozn. 1). sklúčene, opiera sa o svoj meč a počúva šumenie mora (naznačeného vlnovkami), za ním sedí jeho tajomník Mikes Kelemen (Zágoni), a píše pamäti z ich azylového pobytu (Törökországi levelek/Listy z Turecka). Postavy výjavov konca a začiatku sú k sebe otočené chrbtom (ako u Crana anjel života a anjel smrti). Medzi nimi je polkruhový tympanón portálu. Dudits, ako sám podotkol, jednotlivé výjavy zjednotil kvetmi, ${ }^{78}$ tie akoby vyrastali pred pomyselnou architektúrou stupňovitého oblúka, (avšak pri realizácii boli zmenené na vavrínové girlandy s červenými bobulami a s červenými stuhami, ktoré lemujú bočné časti polkruhovej rímsy tympanónu).

Dolná čast' mal'by je situovaná do pol'a tympanónu. Pri Rákociho sarkofágu klačí anjel a kladie naň olivovú ratolest' - symbol zmierenia s Bohom, (ale táto postava je len na návrhu). Na sarkofágu je položený vavrínový veniec s červenou stuhou - symbol úcty. Ostatné vence sú dolu v strede a v rohoch. Ten stredný je na listinách a knihách, ktoré mali pripomínat' Rákociho ako tvorcu nových zákonov. Na listinách sú vročenia; rok 1705 upozorňuje na prvý povstalecký snem v Szécsényi a rok 1906 na uloženie Rákociho pozostatkov v Košiciach. Horná čast' mal'by je zakomponovaná do architektonic-

${ }^{77}$ Rákoci po vypuknutí povstania (1703) získal síce spojenectvo francúzskeho král'a L’udovíta XIV., ktorý mal záujem na oslabení moci Habsburgovcov v Európe, ale výraznejšiu pomoc mu odmietal. Podporil ho finančne a do ,jeho Uhorska" vyslal francúzskeho vyslanca. Po porážke Rákoci odišiel do Pol’ska (1711). Ludovít XIV. mu kúpil panstvo v Jarosławi (v Podkarpati), kde sa o neho starala kňažná Alžbeta Sieniawska (LINK-LENCZOWSKI, A. - POPIOŁEK, B.: Sieniawska Elżbieta Helena 1669 - 1729. In: Polski stownik biografičny 37. Kraków 1997, s. 90). Rákoci sa obával atentátu, preto odcestoval do Gdańska, nastúpil na anglickú lod' a odplával do francúzskeho prístavu Dieppe (1712). Išiel do Paríža, nejaký čas bol vo Versailles a po smrti krála (1715) sa utiahol do kamaldulského kláštora v Grosbois. Meditoval, záhradníčil a písal pamäti. Kláštor opustil iba pri príležitosti návštevy ruského cára Petra I. Vel'kého, a ked' Paríž navštívil sultán Ahmed III. Ten mu ponúkol pomoc, ak mu pomôže bojovat' proti Habsburgovcom. Rákoci to prijal, ale kým prišiel do Konštantínopolu (1717), Habsburgovci s pomocou princa Eugena Savojského Osmanov/Turkov porazili (pri Belehrade) a vyjednali s nimi mier (v Požarevaci). Nato bol Rákoci z Konštantínopolu vyhostený do mesta Tekirdağ (1720). Bližšie KÓNYA 2005, c. d. (v pozn. 1).

${ }^{78}$ ÉBER 1912, c. d. (v pozn. 62). 


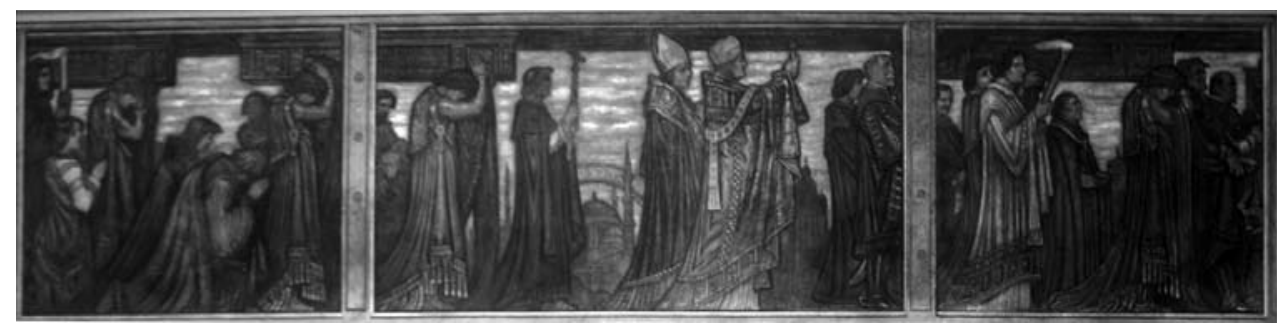

Obr. 9: Andor Dudits: Pohrebný sprievod, horná čast’ Rákociho triptychu, 1914 - 1916, nástenná malba, Dóm sv. Alžbety, Košice. Foto: C Peter Gombos

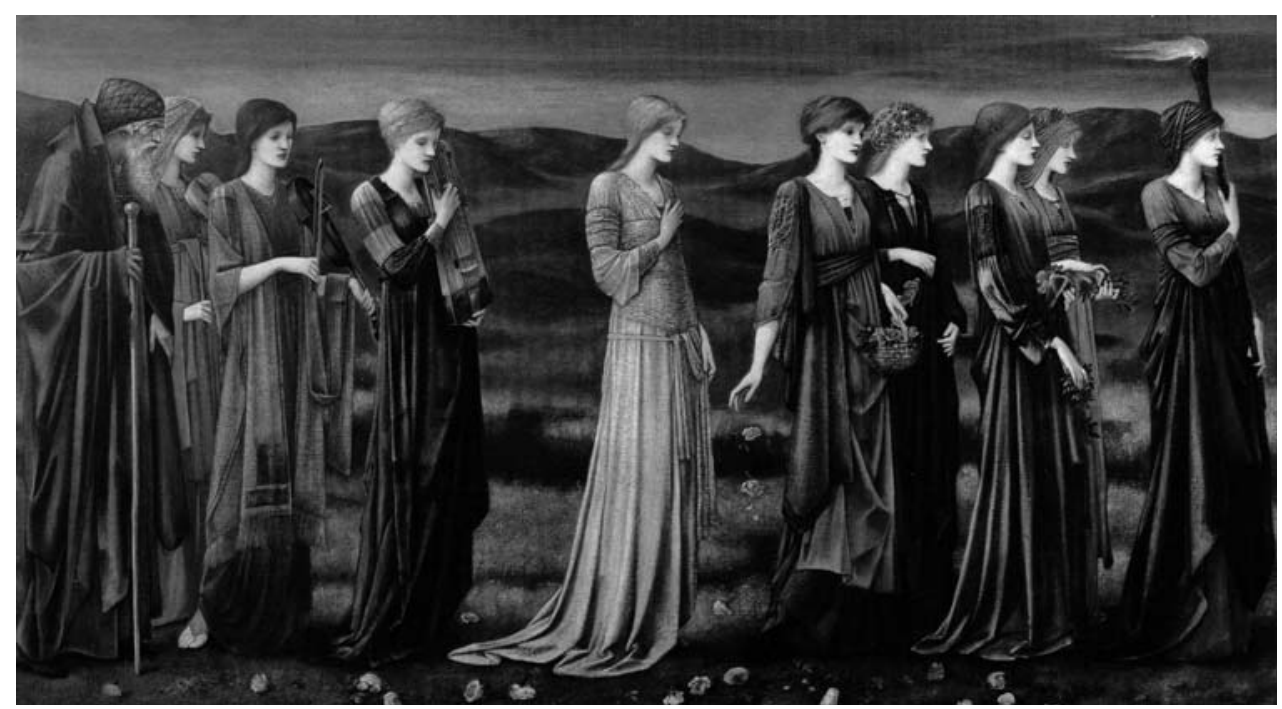

Obr. 10: Edward Burne-Jones: The Wedding of Psyche, 1894 - 1895, olejomal'ba, Královské múzeum krásnych umení, Brusel. Zdroj: wnw. wikiart. org/en/edward-burne-jones/the-wedding-of-psyche-1895

kých rámov steny. $\mathrm{V}$ troch po sebe idúcich výjavoch zachytáva prenesenie pozostatkov Rákociho a jeho blízkych do Uhorska. V každom výjave je sedem postáv, ktoré dovedna vytvárajú pohrebný sprievod. Rovnako odeté postavy v dlhom ozdobnom rúchu so sklonenými hlavami nesú tri rakvy. Dve iné postavy sprievodu majú horiace fakle. Vpredu kráčajú členovia Štátnej pamiatkovej komisie a Uhorskej akadémie vied: Gyula Forster, Kálmán Thaly, Vilmos

\footnotetext{
79 *1857 Košice, Abovská župa - †1916 Herceghalom, Peštianska župa.

$80 * 1842$ Bratislava - †1912 Ženeva.
}

Fraknói, za nimi archivár Lajos Thallóczi/Thallóczy (Stommer), ${ }^{79}$ lekár antropológ Aurel Török (Ponori Thewrewk ${ }^{80}$. Nasledujú cirkevní hodnostári, ktorí vykonali pohrebné obrady: gréckokatolícky mukačevský biskup Július Firczák ${ }^{81}$ a rímskokatolícky pomocný košický biskup Augustín Fischer-Colbrie ${ }^{82}$; sprievod uzatvárajú postavy smútiacich, niektorí $z$ nich kl’ačia a modlia sa. $V$ pozadí stredného výjavu vidno Hagiu Sofiu, symbol Konštantínopolu. ${ }^{83}$

\footnotetext{
81 *1836 Chudl'ovo, Zakarpatie - †1912 Užhorod.

82 *1863 Želiezovce, Tekovská župa - †1925 Košice.

${ }^{83}$ WICK 1941, c. d. (v pozn. 61), s. 340.
} 
Komisia Duditsov návrh označila za dojemný a moderný, ocenila, že nie je patetický, že štylizované postavy majú patričnú vel'kost' a primerane naznačený pohyb. Taktiež sa jej javilo, že Rákociho hrdinskost' je dostatočne vyzdvihnutá. Jednoduchost' výtvarného poňatia podl'a nej korešpondovala s charakterom stredovekých nástenných malieb, rovnako ako plošnost' zobrazenia a zlaté pozadie. Profánnost' výjavov sa jej zdala byt' vyvážená zobrazením posvätného aktu prenesenia pozostatkov. ${ }^{84} \mathrm{Na}$ mal'be nechýbal Duditsov oblúbený motív - husté mračná - ktoré sa stali typické pre jeho tvorbu, čo si všimol už jeho súčasník historik umenia László Éber (Ellenberger). ${ }^{85}$

Mal'ba s rozmermi $8 \times 8,5 \mathrm{~m}$ bola realizovaná minerálnymi farbami a je signovaná $\mathrm{v}$ pravom dolnom rohu, pod koncom drapérie, ktorá prekrýva sarkofág, „DUDITS ANDOR 1914 • 16“ ${ }^{.86} \mathrm{Jej}$ slávnostné odhalenie sa nekonalo a po jej dokončení prebiehali ešte snahy o dotvorenie, osadenie mramorových tabúl' s textami a vytvorenie okna, ktoré mal vyhotovit' už spomínaný „mad’arský preraffaelista“ Miksa Róth. Vzhl'adom na zmenenú politickú a spoločenskú situáciu po I. svetovej vojne $\mathrm{k}$ tomu už nedošlo. ${ }^{87}$

Dobová kritika vnímala Duditsov triptych ako „moderný“, súčasná ho uvádza ako „konzervatívny" ${ }^{\circ 8}$ Medzi Duditsovým návrhom a realizáciou sú viaceré rozdiely. $\mathrm{Na}$ mal'be absentujú motívy ako vel'ký tmavý strom na pozadí v strede, kvety pod schodmi, kniha, anjel pri sarkofágu atd’. Navyše

\footnotetext{
${ }^{84}$ ÉBER 1912, c. d. (v pozn. 62).

${ }^{85}$ ÉBER 1911, c. d. (v pozn. 46), s. 399.

${ }^{86}$ GOMBOŠ, P.: Reštaurovanie nástennej mal'by Apoteóza života Františka II. Rákócziho v Dóme sv. Alžbety v Košiciach. Úvod - Umeleckohistorická analýza: Marta Herucová. In: PALENČÁROVÁ 2016, c. d. (v pozn. 17), s. 160-168 (tu s. 163-164)

${ }^{87} \mathrm{~K}$ plánovanému dotvoreniu vstupu do Rákociho hrobky sa zachovala korešpondencia medzi predsedom MOB Gyulom Forsterom a predsedom vlády Sándorom Wekerleom. Spomína to REISZ 2018, c. d. (v pozn. 30).

${ }^{88}$ RÉVÉSZ 2001, c. d. (v pozn. 8), s. 249.

${ }^{89}$ GOMBOŠ 2016, c. d. (v pozn. 86), s. 163.
}

jednotlivé figúry neboli pôvodne stvárnené svetelne a farebne ako rovnocenné, hlavní protagonisti sú na návrhu výraznejší ako ostatné postavy. Návrh sa javí živší, prepracovanejší a secesnejší.

Struktúra, nanesenie farieb v rôznej hrúbke, ${ }^{89}$ strojené a $\mathrm{v}$ pohybe ustrnuté postavy, ich dlhé drapérie padajúce v rytmických skladoch, opakujúce sa gestá a tlmená, prevažne zemitá, farebnost' budia dojem mozaiky. Zlaté pozadie (s mračnami) to len dotvára. ${ }^{90} \mathrm{Na}$ bočných okrajoch strednej časti sú dramatizujúco temné (böcklinovské) stromy. Sú iné ako na okrajoch situované (ovocné) stromy na Cranovom Moste života alebo (riedke) stromy na kompozične príbuznej Raffaelovej freske Parnasu, kde sú tri stromy $\mathrm{v}$ takom rozvrhnutí, $\mathrm{v}$ akom ich zamýšl'al aj Dudits. ${ }^{91}$

Rákociho matka Helena Zrínska sa až tak nepodobá žene, známej z jej historických portrétov, hoci má perlami zdobené vlasy ako na starom budapeštianskom obraze od neznámeho autora. ${ }^{92}$ Nadýchaným účesom a celkovým zjavom evokuje skôr dobový ženský ideál - zasnenú múzu preraffaelistov a modelku ich obrazov inšpirovaných antickou mytológiou a stredovekou mystikou - slávnu Jane Burden, manželku Williama Morrisa a milenku Danteho Gabriela Rossettiho, ktorá zomrela v roku 1914; zhodou okolností, ked’ Dudits práve začal mal'ovat' košický triptych. Odkazy na umenie preraffaelistov sú aj v hornej časti mal'by: pohrebný sprievod má v sebe niečo z estetického vyznenia svadobného sprievodu Psyché, dielo Edwarda Bur-

\footnotetext{
${ }^{90}$ Secesní umelci sa vracali k zlatému pozadiu, ktoré bývalo na starých mozaikách, ikonách a tabul'ových mal'bách. Zlato symbolicky povyšovalo zobrazené na ikonické. Príkladov je vel'a, obrazy Gustava Klimta, belgického umelca Paula Cauchieho, jeho mal'ba Femme et fillette (1910); zlaté pozadie má aj mozaika Aladára Körösfői-Kriescha Hódolat Hungáriának (Pocta Uhorsku) na fasáde Kultúrneho paláca v Târgu Mureș (okolo 1913), ktorá je Duditsovej mal'be vel'mi blízka. - Bližšie ALAMI, S.: Gustav Klimt - Franen auf Goldgrund und femmes fatales. München 2007.

${ }^{91}$ Fresku vytvoril Raffael 1509 - 1511 v Podpisovej sieni pápeža (Stanza della Segnatura) v Apoštolskom paláci vo Vatikáne. Crane bol paradoxne jeden z Raffaelových obdivovatel'ov, čo bolo $\mathrm{v}$ rozpore $\mathrm{s}$ názormi preraffaelistov, ktorí si cenili umenie pred ním, jeho tvorbu pokladali za príliš mechanickú a príliš odt'ažitú. Bližšie Truth \& Beauty : the Pre-Raphaelites and the Old Masters. Ed.: BURON, M. E. Munich 2018.
} 
ne-Jonesa, Rossettiho žiaka. ${ }^{93}$ Podobnost' je v rytmizácii kompozície a postáv, $\mathrm{v}$ dobovo indiferentných (divadelných) odevoch i v detailoch, akým je dlhý šál ukončený strapcami, u Burne-Jonesa na žene hrajúcej na husle na konci sprievodu a u Duditsa na postavách nesúcich rakvy.

Preraffaelisti sa vyhranili voči akademickému umeniu v roku 1848, chceli mal'ovat' obrazy s hlbokými myšlienkami a dojemnými príbehmi, venovat' sa otázkam života a smrti, vernosti a zrady a podobne, a ked’že to chceli robit's plnou vážnost'ou ako stredovekí umelci, vrhali sa na štúdium prírody, na symbolické významy rastlín, na poéziu a inú literatúru, ktoré im pomáhali vyjadrovat' ich umelecké zámery. Fetišizovali krásu, nemali však žiadne striktné pravidlá a ctili si slobodu osobného prejavu. To ich vzdialilo od nazarénov, ktorí chceli byt' tiež ako stredovekí umelci, ibaže preraffaelisti sa nehodlali obmedzit' len na krest'anské námety, nemenej milovali rytierov a princezné, legendy, mýty, fantáziu. Prít'ažlivost' ich umenia vedela byt' omamná. Mohla vedome alebo nevedome spôsobit' aj to, že sa uhorský bojovník za nezávislost' objavil na košickej mal'be ako rytier v plnej zbroji. V Duditsovom podaní však bolo cítit' istú povrchnost', ktorá poznamenala aj jeho medzivojnovú tvorbu, ked' začal mal'ovat' obrazy koketných južanských a orientálne vyzerajúcich žien.

\title{
Andor Dudits and the Reverberations of Pre-Raphaelite Inspirations in his Painting in Košice
}

\author{
Résumé
}

In the Cathedral of St Elizabeth in Košice, there is a wall painting in honour of Francis II Rákóczi (1914 -1916). Its author is Budapest painter Andor Dudits $(* 1866-\uparrow 1944)$. It belonged to one of the last works done on the theme of anti-Habsburg resistance in painting, which was popular from the lost revolution of $1848 / 1849$ to the millennium celebrations of 1896 (Madarász, Than, Orlai Petrich, Benczúr, Elek de László, Stetka, Révész, Éder, Pataky, Greguss). Rákóczi's grave was found in Thrace by Kálmán Thaly (1889) who initiated a transfer of his remains to Košice (1906). These, together with the remains of the ones close to him, were placed into the adapted northern crypt. The State Monuments Commis-

\footnotetext{
92 Reprodukciu dobového portrétu Heleny Zrínskej publikoval HORVAT, R.: Slike iz hrvatske povijesti (Obrazy z chorvátskej histórie). Zagreb, 1910. Za jej dobový portrét sa považuje najmä neznačený portrét dámy s perlami vo vlasoch a v šatách zdobených hermelínom v zbierke MNM v Budapešti, šírený formou kópií a grafík. Populárny sa stal aj oválny portrét
}

sion announced a competition to paint the adjacent northern wall of the transept. Besides Dudits, Dezső Kölber, Sándor Nagy, Sándor Novák, Rezső Raksányi, Octavian Smigelschi, Viktor Tardos Krenner and Zsigmond Vajda participated in it. Dudits won. He was a descendant of humanist Andrija Dudić of Orehovice $(* 1533-+1589)$, and the son of a doctor Miklós Dudits. He studied under Luigi Rostagni in Budapest, at the Vienna and Munich Academy and at the Julius Benczúr's Master School in Budapest. He made his debut in Munich (1890). At first, he painted genres (Courting, 1893, SNG Bratislava). During the preparation of the millennium celebrations he started to incline to historical painting (Francis II Rákóczi

Heleny Zrínskej od Karola Jakobeya (*1825/1826 Kula, Vojvodina - †1891 Budapešt'), dnes v súkromnom majetku.

${ }^{93}$ Edward Burne-Jones (*1833 Birmigham - †1898 Londýn): The Wedding of Psyche, 1894 - 1895, olej, plátno, 122 x 214,4 cm, Královské múzeum krásnych umení, Brusel. 
comes to the Onod Diet, 1896, HM Budapest). The tendency towards Art Nouveau was reflected in the paintings in the Hungarian Parliament (1897) and in the designs of mosaics $(1906,1908)$. He cooperated with Pre-Raphaelism enthusiasts: Miksa Róth and Aladár Körösföi-Kriesch. Körösfői-Kriesch founded an Art colony in Gödöllő (1901) and published a book on Ruskin and Pre-Raphaelists (1905). Walter Crane exhibited in Budapest (1895, 1900). Among the exhibits of the first exhibition was his graphic of his own painting Bridge of Life, reproduced in Vasárnapi Ujság. Its concept and composition were used by Dudits when creating the painting in Košice. Both works relied on the iconographic model of stages of life. Dudits followed the style of his Art Nouveau work in the sacral space (Bačka Topola, 1908; Brezno, 1909). He made two designs for the Cathedral in Košice, 1908 (unrealized) and 1912 (realized with changes). The first was created together with the sculptor Ede Margó, orig. Morgenstern, and architect Koloman Lux, native of Bujakov, nowadays part of Brezno, and the second one on his own, as the second round of the competition was intended only for painters. The painting has three parts. In the lower is Rákóczi's sarcophagus, in the middle milestones of his life and in the upper part the transfer of his remains to Košice. The middle part begins at the bottom with the figure of Jelena Zrinska, who protects little Francis in her arms, at the $1^{\text {st }}$ stage (left) Rákóczi is as a teenage boy with the Archbishop of Vienna, Sigismund Kollonich, who sent him for reeducation to Jesuits after the imprisonment of his mother. At the $3^{\text {rd }}$ stage he is among his companions, with whom he defied the Emperor, at the top are the closest to him - Miklós Bercsényi and Ádám Vay and he is depicted as the reigning prince on a horse; going down, at the $3^{\text {rd }}$ stage, he leaves his country, goes to the French King Louis XIV standing on the $2^{\text {nd }}$ stage, who, however, sends him by the gesture of his hand into the arms of Sultan Ahmed III standing on the $1^{\text {st }}$ stage (right). Below, there are old Rákóczi with his secretary Mikes Kelemen, orig. Zágoni, who is writing memoirs. Their figures (in the final scene) face back from Jelena with the child (in the opening scene), just like the angel of death and the angel of life in Crane's painting.

There is a funeral procession in three consecutive scenes of the upper part of the painting. Figures in decorative robes carry three coffins, members of the State Monuments Commission and the Hungarian Academy of Sciences lead the procession (Gyula Forster, Kalmán Thaly, Vilmos Fraknói, Lajos Thallóczi, orig. Stommer, and Aurel Török, orig. Ponori Thewrewk), followed by church dignitaries (Bishop of Mukachevo Julius Firczák and auxiliary Bishop of Košice Augustin Fischer-Colbrie) and behind them the other mourners. In the background in the middle scene there is Hagia Sophia, symbol of Constantinople (Istanbul).

Layers of muted earth colours of varying thickness with theatrically forced and stunned in movement figures, long draperies falling in rhythmic stores, repetitive gestures, and a golden background with clouds give the impression of a mosaic. There are (Böcklin like) dark trees on the edges of the central part; trees on the sides, but approached differently, are also in Crane's painting. Jelena Zrinska with fluffy hairstyle and overall appearance, evokes a contemporary female ideal - Jane Morris, née Burden, the Pre-Raphaelite Muse. The references to the art of Pre-Raphaelites is also in the upper part: the funeral procession resembles the aesthetic tone of the wedding procession of Psyche, painted by Edward Burne-Jones. 